\title{
KRYTYKA KULTU W KSIĘDZE „PROROKA SPRAWIEDLIWOŚCI SPOŁECZNEJ" (AMOSA)
}

Tytuł nawiązuje do książki Gabriela Witaszka, ${ }^{1}$ który o krytyce kultu wspomina jedynie w rozdziale Szukanie Boga źródłem życia i odnosi się praktycznie jedynie do Am 5,1-17. Jego zdaniem, szukanie Boga trzeba pojmować w kategoriach egzystencjalnych jako przyjaźń z Bogiem, która „konkretyzowała się w przestrzeganiu zasad sprawiedliwości wobec słabszych i bezbronnych". ${ }^{3}$ Prorok ma zakazywać pielgrzymowania do innych miejsc świętych poza Jerozolimą. Bóg żąda nie pielgrzymek, lecz „odpowiedzialności moralnej”. Ale „nie występuje przeciw kultowi, ale nadaje mu inne znaczenie”: ,postępowanie według zasad sprawiedliwości” i szukanie Boga w sanktuarium w Jerozolimie. ${ }^{4}$ Podobnie w swoim komentarzu postrzegał już tę kwestię E. Zawiszewski. ${ }^{5}$ Amosowa krytyka kultu miałaby dotyczyć „schizmatyckiego”, a więc „,nieprawego”, kult ustanowiony przez Jeroboama I, ${ }^{6}$ a także jego formalizmu, gdyż kult pozbawiony miał być ,usposobienia wewnętrznego”, który znajdował wyraz we właściwej postawie moralnej uczestników kultu żyjących w rozpuście

\footnotetext{
G. W it a s z e k, Amos: Prorok sprawiedliwości społecznej, Lublin 1996.

2 Tamże, s. 166-179.

3 Tamże, s. 168.

4 Tamże, s. 178.

5 E. Z aw is zew s k i, Księga Amosa: Wstęp - przekład - komentarz,
} w: S. Ła c h (red.), Księgi proroków mniejszych: Ozeasza - Joela - Amosa Abdiasza-Jonasza-Micheasza: Wstęp-przekład z oryginalu-komentarz, Pismo Święte Starego Testamentu XII/1, Poznań 1968, s. 172.

6 Pomijając kwestię historycznego anachronizmu tej tezy (opowiadanie z $1 \mathrm{Krl}$ 12 nie jest relacją historyczną; zob. Ch. F r e v e 1, Grundriss der Geschichte Israels, w: E. Z e n g e r i in., Einleitung in das Alte Testament, Kohlhammer Studienbücher Theologie 1,1, Stuttgart 2008, s. 637) warto od razu zauważyć, że prawomocność kultu w najstarszych tekstach Am nie budzi najmniejszych zastrzeżeń (zob. poniżej). 
i gnębiących biednych. Czy G. Witaszek i E. Zawiszewski trafnie przedstawiają Amosową krytykę kultu? Warto od razu zauważyć, że drugi z dwóch proroków piśmiennych, którzy działali w królestwie północnym - Ozeasz - kieruje ostrze swej krytyki przede wszystkim przeciwko religijnej niewierności Izraelitów wobec jedynego Boga JHWH, nawet jeśli nie pomija problematyki etycznej i społecznej (np. Oz 4,1-3). ${ }^{7}$ Czy przesłanie tych dwóch proroków i ksiąg z nimi związanych aż tak bardzo się różni? ${ }^{8}$ Jaką rolę odgrywa kult i jego krytyka w omawianej księdze? Celem niniejszego studium jest prześledzenie wypowiedzi dotyczących kultu w Księdze Amosa, przy uwzględnieniu jej złożoności literackiej.

Księga Amosa jest wyjątkowa pod kilkoma względami: żaden inny prorok tak ostro i zdecydowanie nie występował przeciwko niesprawiedliwości społecznej; kompozycja księgi jest szczególnie staranna, z czym wiąże się wielowiekowe jej przepracowywanie. $Z$ tego też względu jedynie bardzo ostrożnie można wnioskować o historycznej osobie Amosa i trzeba się liczyć z obecnością w księdze koncepcji z bardzo różnych epok. Najpóźniej od ukazania się komentarza H. W. Wolffa Księga Amosa jest postrzegana jako literacko złożona w bardzo dużym stopniu. Z kolei przełomowe znaczenia do postrzegania kompozycji księgi miały studia i komentarz J. Jeremiasa. ${ }^{9}$ Pokazał on, że w ogólnym zarysie księga ta ma kompozycję ramową, w której rozdz. 1-2* z wyroczniami przeciwko narodom są mocno powiązane $\mathrm{z}$ wizjami z rozdz.

7 Zob. np. W. H. S c h m i d t, Wprowadzenie do Starego Testamentu, Bielsko-Biała 1997, s. 168-170, 174-176. Do Oz 4,1-3, który ma charakter sumarycznego wprowadzenia do Oz 4-11, będącego zbiorem mów Ozeasza (oczywiście z rozszerzeniami) J. J e r e m i a s, Der Prophet Hosea, ATD 24,1, Göttingen 1983, s. 59-63.

8 Na podobieństwa, wynikające nie tylko z świadomej aktywności redaktorów ksiąg, i różnice między obiema księgami wskazuje J. Jeremias; zob. t e n ż e, Die Anfänge des Dodekapropheton: Hosea und Amos, w: t e n ż e, Hosea und Amos. Studien zu den Anfängen des Dodekapropheton, FAT 13, Tübingen 1996, s. 34-54, zwł. s. 33-36.

9 Te nż e, Der Prophet Amos, ATD 24,2, Göttingen 1995; t e n ż e, Hosea und Amos. Za J. Jeremiasem podąża również E. Z e $\mathrm{n} g$ e $\mathrm{r}$ i in., Einleitung in das Alte Testament, s. 534-538 czy G. W it a s z e k, Amos: Prorok sprawiedliwości społecznej, s. 45-51. 
7-9*. Obie te kompozycje mają taką samą budowę stroficzną. Otaczają one część środkową rozdz. 3-6*, dzielącą się na precyzyjnie skomponowane dwie części, których początek wyznaczają wprowadzenia 3,1 i 5,1. Centralną pozycję zajmuje kunsztownie zbudowana kompozycją 5,1-17. Księgę zamykają bardzo późne wiersze 9,11-15.

\section{Tekst Am 5,21-27}

Dla rozważanej tutaj kwestii zasadnicze znaczenie ma perykopa 5,21-27 z drugiej części (Am 5-6*) środkowej kompozycji (Am 3-6*). ${ }^{10}$ Am 5-6 składa się klamrowej (ramowej) kompozycji 5,1$-17,{ }^{11}$ która zawiera główne idee teologiczne przesłania prorockiego o szukaniu Boga, oraz dwóch kompozycji wprowadzonych przez „biada” (5,18-27 i 6,1-14), mających częściowo paralelną strukturę. ${ }^{12}$ Pierwsza $\mathrm{z}$ nich zbudowana jest $\mathrm{z}$ dwóch jednostek tekstowych: 5,18-20 - „,biada”, którego tematem jest dzień Pana czy oczekiwanie na dzień Pana, który wbrew nadziejom nie przyniesie zbawienia, lecz zgubę; oraz 5,21-27 - słowa JHWH. Adresatem słowa Bożego są „wy”, którzy zostali w w. 25 utożsamieni z „domem Izraela”.

„21. Znienawidziłem, odrzuciłem ${ }^{13}$ wasze święta

i nie mogę wąchać ${ }^{14}$ uroczystych waszych zgromadzeń, ${ }^{15}$

22. nawet jeśli ${ }^{16}$ składacie mi ofiary całopalne

10 Podczas gdy 3,1 wprowadza słowa JHWH, przy czym w obu częściach nie zachowano konsekwentnie takiego podziału; J. J e r e m i a s, Der Prophet Amos, s. XX.

11 Zob. poniżej.

12 E. Z e nge r i in., Einleitung in das Alte Testament, s. 537; J. J e r e $\mathrm{m}$ i a s, Der Prophet Amos, s. 75, 84-85.

13 Czas przeszły można by tłumaczyć również w czasie teraźniejszym, gdyż za jego pomocą wyrażane były uczucia i emocje, co odnotowuje $\mathrm{H}$. W. Wolff, Dodekapropheton 2: Joel und Amos, BK XIV/2, Neukirchen-Vlyun 1969, s. 303.

14 Por. 1 Sm 26,19.

15 Lub „dzień świąteczny”, „uroczystość”.

16 כִּיאם można rozumieć jako emfazę (,,jednak” czy w przysięgach „,z pewnością”) lub ograniczenie („lecz”, „poza”; zaś w zdaniach czasownikowych „lecz jeśli”), lub jako dwa stojące koło siebie spójniki („tak”, ,jeśli”; „że”, ,jeśli”; „,bo jeśli”; 


\section{i wasze dary ofiarne, których nie chcę, i ofiarę końcową ${ }^{17} \mathrm{z}$ waszych tucznych byków, na którą nie mogę patrzeć. \\ 23. Odsuń ${ }^{18}$ ode mnie hałas ${ }^{19}$ twoich pieśni \\ i dźwięku twoich lutni ${ }^{20}$ nie chcę słuchać!}

„lecz jeśli”, „,nawet jeśli”) - zob. HAL I, s. 449. Sugestia z aparatu krytycznego BHS (może rozwinąć ten skrót tutaj?) ,jakoby zaginęła druga część stychu (jak i uznania pierwszej jego części za dodatek) nie znajduje poświadczenia w świadectwach tekstowych. Nie zmienia to faktu, że tekst może wydawać się zakłócony: brak paralelnej linii i typowego tutaj suf., zmiana podmiotu. Relacje syntaktyczne w tym wierszu można ująć wpierw na dwa sposobów: 1) wszystkie 3 linie (stychy) mogą być niezależnymi zdaniami (pierwsza stałaby w pewnej opozycji do

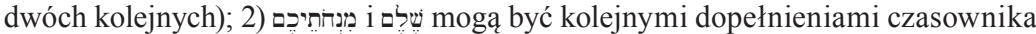
עלה (stojącymi obok עלוֹת), a wtedy zaprzeczone czasowniki w drugiej i trzeciej linii trzeba by przetłumaczyć jako zadania asyndetyczne (podrzędne), za czym zdają się przemawiać akcenty masoreckie (zob. powyższe tłumaczenie). Do tego dochodzi problem początkowego אב כִ כִיאם nie da się ująć jako prostego warunku ani כִִּ w znaczeniu emfatycznym, bo wtedy nie powstałaby zrozumiała całość nie wiadomo byłoby dlaczego w przypadku składania ofiary całopalnej, Bóg

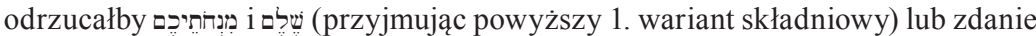
byłoby urwane, brakowałoby zdania głównego (przy 2. wariancie). W takim razie w. 22 trzeba rozumieć w opozycji do w. 21: „,nawet jeśli/lecz składacie/złożycie mi ofiary". E. Z a w i s z e w s k i, Księga Amosa, s. 226, unika problemu, rozbijając jednak wyraźny paralelizm drugiej i trzeciej linii. H. W. Wolff, Dodekapropheton 2, s. 303n., dodając uwagę o kronikarskim sformułowaniu העלה עלוֹ, widzi w pierwszej linii dodatek glosatora, tłumacząc ją jako tzw. Exzeptionssatz (zob. Wilhelm Gesenius' Hebräische Grammatik: völlig umgearbeitet von E. Kautsch, Hildesheim-Zürich-New York 1991, § 163c): „chyba że złożycie mi ofiary całopalne”.

17 Rzeczownik w 1. poj.. to hapaxlegomenon, którego znaczenie jest niejasne (HAL II, s. 1421-1423). Korekta (BHS) na st. cs. pl. odpowiadałaby użyciu tego rzeczownika w Starym Testamencie, ale brak poświadczenia każe zachować 1. poj., który trzeba ująć jako st. cs. lub apozycję.

18 Liczba poj. - przy czym może chodzić o inf. abs. (E. Z a w i s z e w s k i, Księga Amosa, s. 226) - po 1. mn. w w. 21-22 podobnie jak w przypadku suf. zaskakuje, ale sugerowana korekta (BHS) dokonana zostałaby wbrew świadectwom tekstowym. Trzeba szukać innego wyjaśnienia dla liczby pojedynczej (zob. poniżej).

19 Też „mnóstwo” lub „podniecenie” (HAL).

20 HAL: „dzban”; „harfa”. Jednak raczej nie chodzi o harfę, bo znaczenie wyrazu wskazuje na pudło rezonansowe w kształcie dzbana. 


\section{Ale niech wytryskuje ${ }^{21}$ jak woda prawo} i sprawiedliwość jak rzeka nieustannie!

\section{Ofiary rzeźne i dar ofiarny ${ }^{22}$ przynosiliście mi na pustyni \\ przez czterdzieści lat, domu Izraela? \\ 26. I nosiliście ${ }^{23}$ Sakkuta, ${ }^{24}$ waszego króla, i Kewana, ${ }^{25}$ wasze bożki, gwiazdę waszych bogów, ${ }^{26}$ których sobie uczyniliście?}

21 dosłownie oznacza ,toczyć się” czy „, גל גלל niż chciałby K. K o c h, Die Entstehung der sozialen Kritik bei den Propheten, w: H. W. W o $1 \mathrm{ff}$ (red.), Probleme biblischer Theologie. Gerhard von Rad zum 70. Geburtstag, München 1971, s. 252, życzeniowe ujęcie krótkiego impf. nie może budzić zastrzeżeń, podobnie jak przeciwstawne znaczenie spójnika w (zob. Wilhelm Gesenius' Hebräische Grammatik, § 154a).

22 Przypuszczenie, że cały wiersz ze względu na zbyt długie metrum oraz brak paralelizmu (proza) jest dodatkiem (BHS) jest zagadnieniem literacko-krytycznym. Brak וּמִּנזָה w jednym manuskrypcie hebrajskim, do czego trzeba by dodać, że rzeczownik ten stoi w 1 . poj. i bez przedimka, mógłby sugerować, że słowo jest dodatkiem. Z kolei G* pomija słowo „pustynia”.

23 Propozycja zmiany na pi. (BHS) = „wysoko podnosić”, „wznosić”, „wywyższać" (por. Am 4,2) jest pozbawione podstaw, nawet jeśli dotyczy jedynie wokalizacji i upodabniałoby wiersz do konstrukcji znanej z 2Sm 5,12, chyba że chciałoby się przekształcić go w zapowiedź kary jak np. w 4,2b; por. H. W. W o $1 \mathrm{ff}$, Dodekapropheton 2, s. 310. Przeciwko ujęciu pf. (cons.) jako zapowiedzi słusznie wypowiada się J. J e r e m i a s, Der Prophet Amos, s. 74 przyp. 4.

24 Właściwa wokalizacja akadyjskiego imienia to Sakkut, a nie Sikkut (BHS i komentarze, np. H. W. W o 1 f f, Dodekapropheton 2, s. 304 czy J. J e r e m i a s, Der Prophet Amos, s. 74 przyp. 5). Wokalizacja w TM bazuje na שִ , tj. ,podpora” czy „monstrum”. W G, s’ (też S i V) czytamy: „namiot Molocha”, z tego płynie propozycja zmiany na „namiot/szałas” lub „odlany bożek” (BHS). Jednak lekcja ze starożytnych przekładów może być interpretacją już słabo znanego w późniejszym czasie Sakkuta (w połączeniu z מלך).

25 Być może chodzi o Kewana (a nie Kijjuna) - syryjskie i aramejskie określenie Saturna (por. BHS i HAL). Do wokalizacji poprzedni przyp.

${ }^{26}$ Wyrażenie to będące kolejną apozycją wygląda na glosę, tym bardziej że rzeczownik ,gwiazda” stoi w 1. poj. (zob. BHS). 
27. I (dlatego) zawiodę was na wygnanie poza Damaszek

- rzekł JHWH, Bóg zastępów to jego imię". ${ }^{27}$

Perykopa, która formalnie jest zbliżona do wyroczni posłańca (zapowiedzi kary z uzasadnieniem, tj. Scheltrede w w. 21-26* i Drohwort W w. $\left.27^{*}\right),{ }^{28}$ rozpoczyna się od ostrej krytyki uroczystości kultowych w w. 21-23. Dwa początkowe asyndetycznie połączone czasowniki podkreślają niechęć Boga do świąt i uroczystości ofiarniczych. Boża niechęć do wąchania dotyczy składanych w czasie ceremonii kultowych ofiar i oznacza ich odrzucenie (por. Rdz 8,21). Myśl tą rozwija w. 22, który przywołuje różne rodzaje ofiar, zaznaczając, że Bóg ich nie przyjmuje ( רצה to terminus technicus na przyjęcie, a z przeczeniem na odrzucenie daru ofiarnego przez kapłana, ${ }^{29}$ zaś נבט hi. trzeba kojarzyć z wysłuchaniem prośby, a jeśli stoi z przeczeniem, to z jej odrzuceniem ${ }^{30}$ ). Nie ma większego znaczenia, jakie rodzaje ofiar określają poszczególne terminy. ${ }^{31}$ Uwagę zwraca jedynie wyrażenie: (JHWH) עלה עלוֹת ל (hi.), które pojawia się jeszcze jedynie w 1Sm 6,14 oraz Ezd 3,6; 1Krn 16,40; 23,31; 2Krn 29,12, gdzie odnosi się do najważniejszej kategorii ofiar - ofiary całopalnej. Dlatego zdanie

27 Końcowe zdanie rzeczownikowe wydaje się dodatkiem (por. tamże), wtedy wiersz byłby krótki, co mogłoby wskazywać na zakończenie.

28 Zob. W. H. S c h m i d t, Wprowadzenie do Starego Testamentu, s. 157-158.

29 G. G e r l e m a n, רצה, w: E. J e n n i, C. W e s t e r m a n n (wyd.), Theologisches Handwörterbuch zum Alten Testament, t. 1-2, München-Zürich 1984, s. 810-812, zwł. s. 812 (dalej: THAT).

${ }^{30}$ H. R inggre n, נבט, w: G. J. B ot te rwe ck, H. Ringgren, H.-J. F a b r y (wyd.), Theologisches Wörterbuch zum Alten Testament, t. V, Stuttgart-Berlin-Köln-Mainz 1973, s. 140 (dalej: TWAT).

31 מִנְחדה (pl. jest rzadki) to ogólne określenie daru ofiarnego (tak u najstarszych proroków), które w późniejszym okresie staje się przede wszystkim słowem dla jarskiej ofiary z pokarmów (mąka z oliwą, czasami z kadzidłem); zob. H.-J. F a b r y, M. W e i n fe 1 d, מְנְחז, w: TWAT IV, s. 987-1000; J. J e r e m i a s, Der Prophet Amos, s. 78 przyp. 10. של (poza tym wierszem w Starym Testamencie zawsze liczba mnoga, przy czym nie ma pewności, czy chodzi rzeczywiście o liczbę mnogą) to termin, który do dzisiaj nie został wystarczająco wyjaśniony, ale zadziwiająco często stoi na końcu list ofiarniczych, tak że odnosić się do ofiary końcowej; zob. T. S e i שלמִמים w: TWAT VIII, s. 101-110. 
to jest prawdopodobnie późniejszym, powygnaniowym rozszerzeniem (związanym z teologią kronikarską) ${ }^{32}$ i można go rozumieć jako Exzeptionssatz: „chyba że składacie mi ofiary całopalne", ${ }^{33}$ co jednak oznaczałoby zupełne odwrócenie sensu krytyki prorockiej, oskarżeniem o niewystarczające ofiarnictwo. W obecnym kształcie tekstu wyrażenie to zdaje się wyrażać myśl, że nawet składanie tak wartościowych ofiar jak całopalne nic nie zmienia, gdyż Bóg ich nie przyjmuje. W napomnieniu z w. 23 Bóg wyraża niechęć do kultowych pieśni. ${ }^{34} \mathrm{~W}$ wierszu tym niespodziewanie pojawia się liczba pojedyncza, ${ }^{35}$ która może wskazywać na nieco innego adresata niż w w. 21-22: kapłana czy osobę odpowiedzialną za muzykę ${ }^{36}$ i śpiew, prowadzącego śpiew. Ale nie da się całkowicie wykluczyć, że adresatem jest zgromadzenie kultowe jako całość lub każdy z osobna uczestnik takiego zgromadzenia. ${ }^{37}$ Wtedy adresat byłby identyczny z ,wy” z poprzednich wierszy. Boże odrzucenie kultu ma wymiar totalny, Bóg odwraca swój węch, oczy i uszy, tj. wszystkie swoje „zmysły”.

Wiersz 24 różni się od wszystkich pozostałych, gdyż jest życzeniem sformułowanym w ogólny sposób (w 3. os.). Odbiorca, który

32 עלה to najczęściej wymieniany w Starym Testamencie rodzaj ofiary, która w całości przeznaczona jest dla Boga, tak że ani składający, ani kapłan nie mogli z niej jeść. W tzw. Kronikarskim dziele historycznym staje się najważniejszą ofiarą, zastępując także inne rodzaje ofiar ze wcześniejszych przekazów. Miała być składana regularnie, do czego miała służyć świątynia (2Krn 2,3); zob. D. K e 11 e r m a n n, עֵוללה ,עלה w: TWAT VI, s. 105-122.

33 Zob. powyższą uwagę do tłumaczenia.

34 Zob. R. F i c k e r, שיר, w: THAT II, s. 895-897: wyrażona w ustalonej formie językowej modlitwa do Boga, najczęściej przy towarzyszeniu instrumentów (זמר). המון odnosi się przede wszystkim do hałasu, który może wiązać się z wielością, tłumem (ludzi, zwierząt itp.), a tutaj z męczącymi wrażeniami akustycznymi; por. H. W. W o $1 \mathrm{ff}$, Dodekapropheton 2, s. 308.

35 Do tego zob. tamże.

36 נבֶל to najpewniej instrument strunowy, mający pudło rezonansowe przypominające dzban (Ps 33,2; 144,9 wspominają o dziesięciu strunach, wskazując ponadto na jego użycie w kulcie); tamże i powyżej.

37 Zob. Wilhelm Gesenius' Hebräische Grammatik, § 124o. 
mógł być zdziwiony niechętnym stosunkiem Boga do kultu, który uchodził przecież za nakazany przez Boga sposób utrzymywania z Nim łączności (np. Rdz 8,20nn.), uzyskuje teraz wyjaśnienie: tym, czego Bóg oczekuje, jest prawo i sprawiedliwość. پִ jest pojęciem ze sfery prawno-sądowej, oznaczającym przede wszystkim akt przywrócenia naruszonego niewłaściwym postępowaniem porządku społecznego, czyli wyrok sądowy, określenie, kto jest winny lub niewinny, a w tym drugim przypadku jest bliski znaczeniowo ocaleniu, ratunkowi. ${ }^{38} \mathrm{Z}$ kolei צִ צִרקה wykracza poza zwykłe realizowanie obowiązków wobec innego członka społeczności, a spełniana jest przez udzielanie pomocy, wierność i lojalność. Pojęcie ma wymiar społeczny, oznacza harmonijne funkcjonowanie społeczności, obejmując zarówno lojalne postępowanie względem bliźniego, jak i jego efekt w postaci przestrzeni życiowej, w której egzystencja człowieka nie jest zagrożona. Bóg oczekuje zatem, z jednej strony, wzajemnej lojalności i troski o potrzebujących i słabych, a z drugiej, właściwego sposobu rozwiązywania konfliktów społecznych, tak by chronione były prawa słabszych, a cała społeczność wzmacniana. ${ }^{39}$ Oczekiwanie to zostało wyrażone za pomocą porównań do tryskającego źródła i płynącej wody, które wskazują na obfitość i ożywczy charakter tych wartości. Bez wzajemnej pomocy i lojalności oraz sprawiedliwego sądzenia wszystkie wysiłki kultowe ludu są pozbawione sensu, bo Bóg odwraca się nich, co jest tożsame $\mathrm{z}$ odmową okazania ludziom swej zbawczej przychylności i społeczności z Bogiem.

Kolejne dwa wiersze (w. 25-26), które najlepiej jest ująć jako pytania retoryczne (dysputacja, Disputationswort), ${ }^{40}$ są pod kilkoma względami zaskakujące. Pierwsze pytanie retoryczne (w. 25) jest zaadresowane do „domu Izraela”, który inaczej niż „dzieci Izraela”

38 G. L i e d k e, שפ, w: THAT II, s. 999-1009.

39 Zob. J. J e r e m i a s, Der Prophet Amos, s. 80.

40 Do tego gatunku W. H. S c h m i d t, Wprowadzenie do Starego Testamentu, s. 217; J. B e g r i c h, Studien zu Deuterojesaja, TB 20, München 1963, s. 48-53 i krytycznie H.-J. H e r m i s s o n, Diskussionsworte bei Deuterojesaja: Zur theologischen Argumentation des Propheten, EvTh 31/1971, s. 665-680. 
odnosi się nie tyle do ludu, ile do organizacji społecznej ${ }^{41}$ czy państwowej z jej instytucjami (królem) i kultem (por. Am 5,1.3.4; 6,1.14 oraz 7,10 i wtórny 9,942). O ile זִ - ofiara rzeźna, tj. polegająca na zarżnięciu zwierzęcia, a nazwa ta odnosi się też do całego rytuału ofiarniczego wraz z biesiadą ( נג hi. może być terminem odnoszącym się do przynoszenia daru ofiarnego ${ }^{43}$ - występuje w liczbie mnogiej, ${ }^{44}$ to מִנְחזה (znana z w. 22) - w pojedynczej. To drugie pojęcie zostało użyte w późniejszym sensie, tak by wiersz mówił o ofiarach rzeźnych i pokarmowych (wegeteriańskich), ${ }^{45}$ jest więc wtórnym uzupełnieniem. Pustynia, okres wędrówki przez pustynię czy doświadczenia pustyni, ma w Starym Testamencie wymiar prototypiczny. Z jednej strony, to okres miłości Bożej, przymierza, a z drugiej, niewierności, życia odstępczej generacji. Jest więc okresem ocenianym niezwykle różnorodnie, przy czym znacznie rzadziej spotykamy pozytywne wspomnienia o pustyni (Pwt 32,10; Oz 9,10; Jr 31,12) jako „okresie narzeczeństwa" Boga z Izraelem (Jr 2,2-3), bezpiecznej drodze (Pwt 8,15; 29,4; Am 2,10 itp.). Idealizacja tego czasu jest natomiast charakterystyczna dla przedwygnaniowego profetyzmu. Jak się wydaje, także w Oz 9,10 pustynia kojarzona jest z czasem prawdziwej społeczności z Bogiem, podczas gdy obfitość Ziemi Obiecanej miała doprowadzić do wielości ofiar i odstępstwa $(\mathrm{Oz} 8,11-13 ; 10,1-2) .{ }^{46}$ Mimo braku kultu ofiarniczego jest to okres bliskiego kontaktu z Bo-

41 Zob. E. J e n n i, בית; w: THAT I, s. 309-311.

42 O wtórności 9,8-10 J. J e r e m i a s, Der Abschluß des Amosbuchs (Am 9,7-15), w: t e n ż e, Hosea und Amos, s. 272-276; t e n ż e, Der Prophet Amos, s. 129-130.

43 Zob. H. R i ng g r e n, vgn, w: TWAT V, s. 236.

44 Może to być też określenie zwierzęcia, które składane jest w ofierze, w liczbie mnogiej rzeczownik ten w 2Krn 7,1 odnosi się do tłustych części zwierzęcia; zob. J. B e r g m a n, H. R i n g g r e n, B. L a n g, זבח, w: TWAT II, s. 512-531.

45 Zob. powyższy przypis oraz Jr 33,18 - do datowania W. H. S c h m i d t, Das Buch Jeremia: Kapitel 21-52, ATD 21, Göttingen-Bristol 2013, s. 171; Joz 22,29 por. H. W. H e r z b e r g, Die Bücher Josua, Richter, Ruth, ATD 9, Göttingen 51973, s. 125; Ps 40,7 - E. Z e n g e r, Psalmen Auslegungen 1: Mit meinem Gott überspringe ich Mauern, Freiburg-Basel-Wien 2003, s. 96-98; Dn 9,27.

46 Zob. J. J e re m i a s, Der Prophet Amos, s. 81. O wielości wyobrażeń związanych pustynią S. Ta 1 m o n, מִדְברו, w: TWAT IV, s. 663-693. 
giem, wręcz konstytutywnego w dziejach Izraela. Jednak według wielu tekstów, takich jak Wj 5,1; 7,16 itp., na pustyni miano składać Bogu ofiary. ${ }^{47}$ Wiersz $25^{*}$ zdaje się zatem poświadczać wczesny etap rozwoju przekazów starotestamentowych (ustnych czy spisanych), w których opowiadanie o pustyni nie było jeszcze powiązane z tzw. perykopą synajską. Natomiast „czterdzieści lat” dla pobytu na pustyni pojawia się jeszcze, z wyjątkiem Am 2,10, ${ }^{48}$ jedynie w tekstach deuteronomistycznych (Pwt 1,3; 2,7; Joz 6,6) i kapłańskich (Wj 16,35; Lb 14,33n.). Czterdzieści lat odpowiadało długości ludzkiego życia, tj. jednej generacji (por. Ez 29,11). Wzmianka ta jawi się więc jako powygnaniowe rozszerzenie.

Jeszcze trudniejszy jest w. 26. Jeśli powyżej właściwe ustalono brzmienie imion bóstw, to są one związane z asyryjsko-babilońskim kultem astralnym, a ściślej z kultem Saturna. Do kontaktu z tymi kultami mogło dojść po upadku Samarii i związanymi z nim przesiedleniami (2Krl 17,19-31) lub w okresie wygnania (co zdaje się poświadczać Iz 40,26). ${ }^{49}$ Bóstwa te tytułowane są „królem” i „gwiazdą bogów” (oba określenia w liczbie pojedynczej), co sugeruje kulty astralne, w których szczególna, królewska i przywódcza, rola miała przypadać Saturnowi. Noszenie bóstwa przywodzi na myśl mezopotamskie przedstawienia modlącego się trzymającego sztandar, na którym nad głową bóstwa widać gwiazdę. ${ }^{50} \mathrm{O}$ noszeniu bóstw wspomina Deuteroizajaszowa krytyka bałwochwalstwa (Iz 45,20). Przypuszczalnie wtórnie wtrącone zostało jeszcze określenie

47 Dlatego J. A. Motye r, The Message of Amos, The Bible Speaks Today, Leicester-Downers Grove, Illinois 1974, s. 134-136, sądzi, że odpowiedzią na to pytanie retoryczne jest „tak”, co prowadzi go do zupełnie nieprawdopodobnej interpretacji o dwóch sposobach doświadczania Bożej zbawiennej łaski: ofiarnictwo i posłuszeństwo prawu.

48 J. J e r e m i a s, Der Prophet Amos, s. 26, 80 przyp. 17; H. W. W o 1 f f, Dodekapropheton 2, s. 206, według którego cały wiersz jest wtórny, deuteronomistyczny.

49 Tak J. J e r e m i a s, Der Prophet Amos, s. 81. H. W. W o 1 f f, Dodekapropheton 2, s. 310, wiąże go z wydarzeniami z $2 \mathrm{Krl} 17$, mimo że wiersz przypisuje redakcji deuteronomistycznej.

${ }^{50}$ Tamże. 
„bożki wasze” w liczbie mnogiej. ${ }^{51}$ Krytyka bożków, ich wizerunków jako zrobionych przez ludzi, nie jest w Starym Testamencie odosobniona (np. Wj 20,4; Pwt 5,8 i 4,16.24; Kpł 26,1 czy Ez 16,17; por. też Ez 7,20). Dodatek ten pochodzi najwcześniej z czasów wygnaniowych.

Zapowiedź kary zawarta została w ostatnim w. 27: Bóg sam (1. os.) wygna odbiorców ,poza Damaszek”. Użyty przyimek sugeruje rejon koło Damaszku (por. Jr 22,19), ${ }^{52}$ w każdym razie o Asyrii nie ma jeszcze mowy. ${ }^{53}$ Całość zamyka formuła pokazująca, że prorok przekazuje nie swoje, lecz Boże słowa. Zaś końcowe zdanie rzeczownikowe: „Bóg zastępów to imię jego” jest hymnicznym rozszerzeniem, ${ }^{54}$ opiewającym Boże panowanie w historii świata.

Omówiony fragment zawiera najostrzejszą krytykę kultu w Księdze Amosa. ${ }^{55}$ Lud mógłby się obyć bez kultu i ofiarnictwa, jak to było w okresie wędrówki po pustyni (w. $25^{*}$ ). Kult w żaden sposób nie gwarantuje łączności z Bogiem (w. 21-23*). Warunkiem, by kult, ofiary, prośby i dziękczynienia docierały do Boga, jest właściwe postępowanie, znajdujące wyraz przede wszystkim w trosce elit o biedaków i pokrzywdzonych, oraz w sprawiedliwym rozstrzyganiu sporów sądowych. W przeciwnym razie wszelkie religijne, kultowe usiłowania wywołują jedynie Bożą irytację (smród ofiar, nieznośny hałas pieśni), a w konsekwencji sprowadzają Bożą karę. Warunkiem

$51 \mathrm{O}$ Szerzej - oznacza m. in. statuę czy wizerunek kolumnowy (por. 2Krl 11,18) lub wszelkie wizerunki, nie tylko bóstw (np. 1Sm 6,5.11); H. W i l d b e r g e r, צֶ, w: THAT II, s. 556-558. Do Am 5,26 zbliżone wydają się Ez 7,20; 16,17; 23,14.

52 J. J e r e m i a s, Der Prophet Amos, s. 82, uważa, że wyrażenie to odzwierciedla doświadczenie wojen z Aramejczykami.

53 Zob. H. W. Wo $1 \mathrm{ff}$, Dodekapropheton 2, s. 311 (por. Am 4,3).

54 Może pochodzić z tzw. hymny imiesłowowego; zob. F. C r ü s e m a n n, Studien zur Formgeschichte von Hymnus und Danklied in Israel, WMANT 32, Neukirchen-Vlyun 1969, s. 47-154. Chodzi więc nie tyle o imię własne, ile o zwrot wskazujący na Boże panowanie w stworzeniu, naturze i świecie; zob. A. S. v a n d e r W o u d e, שֶ, w: THAT II, s. 960-961.

55 J. J e r e m i a s, Der Prophet Amos, s. 77. 
łączności z Bogiem jest nie kult, lecz sprawiedliwość społeczna. ${ }^{56}$ Późniejszy redaktor dodał do krytyki społecznej oskarżenie o bałwochwalstwo, mające być przypuszczalnie ostrzeżeniem dla późniejszych odbiorców, że czczenie innych bóstw może doprowadzić do katastrofy, jakiej doświadczył północny Izrael.

\section{Inne fragmenty związane z krytyką kultu}

\section{Szukanie Boga}

Pierwsza część (Am 3-4*) centralnej kompozycji Am 3-6* składa się z wprowadzenia $(3,1-3)$ i trzech literacko złożonych mów: 3,3-8 o przymusie prorockiego zwiastowania nieszczęścia; 3,9-4,3 to przesłanie skierowane przeciwko Samarii i jej elitom; w 4,4-13 dominuje kwestia odrzuconego wezwania do nawrócenia (4,6-13). Fragment 4,6-13 jest poematem złożonym z 6 strof, czymś w rodzaju liturgii pokutnej, pochodzącej najwcześniej z początku okresu wygnania babilońskiego, czyli pierwszych dekad VI w. przed Chr. ${ }^{57}$ Natomiast 4,4-5 odnoszą się do pielgrzymowania do Betel i Gilgal oraz sprawowanego tam kultu, a tym samym wprowadzają w tematykę całego rozdz. 5.

„Idźcie do Betelu, aby popełniać ${ }^{58}$ przestępstwa, do Gilgal, aby pomnożyć jeszcze przestępstwa! I przynieście o poranku wasze ofiary rzeźne, trzeciego dnia wasze dziesięciny!

56 Tekst ten odcisnął głębokie piętno na przekazach starotestamentowych: Oz 6,6; 8,13; Iz 1,10-17, a później Jr 6,19-21; 14,11n.; Mi 6,6-8; M1 1,10; 2,13.

57 Szczegóły w J. J e r e m i a s, Der Prophet Amos, s. 47-48; t e n ż e, Amos 3-6: Beobachtungen zur Entstehungsgeschichte eines Prophetenbuches, w: t e $\mathrm{n} \dot{\mathrm{z}} \mathrm{e}$, Hosea und Amos, s. 146-156.

58 Lub: „i popełniajcie”, ale następstwo dwóch spójnikowo połączonych zdań w impt. może wyrażać skutek; zob. Wilhelm Gesenius' Hebräische Grammatik, $\S 110 f ;$ J. J e r e m i a s, Der Prophet Amos, s. 46 przyp. 1. 
I spalcie w ofierze ${ }^{59} \mathrm{z}$ zakwaszonego ciasta ${ }^{60}$ jako ofiarę dziękczynną!

I wzywajcie do darów dobrowolnych głośno, ${ }^{61}$

bo tak to kochacie, Izraelici (dzieci Izraela)! - wyrocznia Pana JHWH".

Prorok wzywa do pielgrzymowania do świątyń w Betel i Gilgal, wchodząc w rolę kapłanów, którzy zachęcali w ten sposób do sławienia Boga, dziękowania Mu i uniżenia się przed Nim w świątyni (por. Ps 95; 96; 100). Betel było, jak się wydaje, centralną świątynią królewską w północnym Izraelu (związaną z tradycjami o Jakubie - Rdz 28,10-28; 35,1-7; zob. też 1Krl 12,27-30, przy czym nigdzie w Księdze Amosa sanktuarium to nie jest łączone ze złotym bykiem, cielcem), zaś Gilgal w dolinie Jordanu miało być miejscem świętym upamiętniającym przejście Izraelitów przez Jordan i podbój Kanaanu (Joz 4). ${ }^{62}$ Jednak wezwanie okazuje się od razu sarkastyczne, gdyż celem pielgrzymowania jest popełniania ciężkim wykroczeń, mnożenie ich (פשע). ${ }^{63}$ Nagromadzenie czasowników w trybie rozkazującym podkreśla zaangażowanie adresatów w czynności kultowe, które bardzo lubią, a których z kolei Bóg nienawidzi (por. 5,21).

59 W TM inf. abs., który może zastępować każdą formę osobową czasownika (np. impt. jak w Jr 19,1). Mimo to może dziwić jego pojawienie się w szeregu imperatywów, dlatego chętnie poprawiany jest na impt. pl; BHS; H. W. W olff, Dodekapropheton 2, s. 248) Korekta jest jednak zbędna, tak m. in. J. J e r e m i a s, Der Prophet Amos, s. 46 przyp. 2; W. R u d o l p h, Joel, Amos, Obadja, Jona, KAT XIII/2, Gütersloh 1971, s. 170 por. Iz 37,30 (K) i Wilhelm Gesenius' Hebräische Grammatik, § 113z.

${ }^{60}$ Mimo że według Kpł 2,11 była to zakazana ofiara, to inaczej ma się sprawa w przypadkach opisanych w Kpł 7,13; 3,17 i Am 4,5.

${ }^{61}$ Dosłownie: „ogłaszajcie” - do przekładu H. W. W o 1 f f, Dodekapropheton 2; tak J. J e r e m i a s, Der Prophet Amos, s. 46; E. Z a w i s z e w s k i, Księga Amosa, s. 211 przyp. 5.

${ }_{62}$ Nie ma racji E. Zawiszewski, (tamże, s. 211), że z powodu przedimka (a nie „rodzajnika”) nie jest to nazwa własna, lecz określenie instalacji kultowej (kręgu kamiennego); zob. HAHAT; H. W. W o $1 \mathrm{ff}$, Dodekapropheton 2, s. 258.

${ }^{63}$ Zob. R. K n i e r i m, פַּ, w: THAT II, s. 488-495. Rdzeń ten pojawia się dwa razy, co trzeba ujmować jako emfazę. 
Wykroczeniami tymi nie są kult czy czynności kultowe jako takie, lecz kult, pielgrzymowanie i składanie ofiar służą pomnażaniu nieprawości. W jaki sposób? - Tego prorok nie mówi wprost, ale można się tego domyślać, a pewność uzyskuje się, gdy sięgnie się do Am 5 (co również wskazuje na to, że 4,4-5 są wprowadzeniem do rozdz. 5) ${ }^{64}$ gdzie pielgrzymowanie do Betel i Gilgal stoi w opozycji do szukania dobra. Ponieważ naprzeciwko dobra stoi zło, to zło wiąże się ze świątyniami czy miejscami świętymi w Betel i Gilgal. Dobro, o którym mowa, polega na sprawiedliwych sądach $(5,15)$ i niewyzyskiwaniu ubogich $(5,10-12)$. ${ }^{65}$ Zaś pielgrzymowanie i składanie ofiar (różnego rodzaju) ${ }^{66}$ służą Izraelitom do tego, by w zadufaniu czynić zło, szerzyć wyzysk i w spokoju cieszyć się swoim bogactwem (por. 3,9-4,3*). Kult ma zapewnić powodzenie, przychylność Boga, ale jest to złudna nadzieja, gdyż Bóg w sytuacji szerzącej się nieprawości odrzuca kult jako sposób łączności z Nim $\left(5,21-27^{*}\right)$.

Centralnym tekstem w Am jest 5,1-17*, z teologicznie ważnym motywem szukania dobra i Boga. Nie tylko wyznacza on środek kompozycji księgi, ale ma także koncentryczną strukturę: 5,1-3 + 5,16-17: śmierć i żałoba / 5,4-6 + 5,14-15: życie oraz szukanie Boga i dobra / 5,7 + 5,10-13: łamanie prawa / 5,8-9: hymniczne jądro (wtórne) ${ }^{67}$

„1. Słuchajcie tego słowa, które ja podnoszę przeciwko wam jako pieśń żałobną, domu Izraela:

2. «Upadła, już więcej nie powstanie panna Izrael,

${ }^{64}$ Szczegółowo J. J e r e $\mathrm{m}$ i a s, Die Mitte des Amosbuches (Am 4,4-13; 5,1-17), w: t e n ż e, Hosea und Amos, s. 198-213.

65 Zob. poniżej.

${ }^{66}$ Zob. komentarze, np. H. W. W o $1 \mathrm{ff}$, Dodekapropheton 2, s. 259; J. J e r e m i a s, Der Prophet Amos, s. 49.

${ }^{67}$ O kunsztowności kompozycji świadczy nie tylko ramowa struktura, ale i dosyć regularny rytm oraz paralelizmy i chiazmy. Nie ma tutaj miejsca na dokładniejsze przedstawienie poetycko pięknej budowy tego poematu. Zob. J. d e Wa a rd, The Chiastic Structure of Amos V 1-17, VT 27/1977, s. 170-177; J. J e r e m i a s, Die Mitte des Amosbuches (Am 4,4-13; 5,1-17); t e n ż e, Der Prophet Amos, s. 61-63; por. już obserwacje W. R u d olp h, Joel, Amos, Obadja, Jona, s. 184-186. 
leży na swojej ziemi, nie ma nikogo, kto by ją podniósł».

3. Bo tak rzekł Pan ${ }^{68}$ JHWH:

«Miasto: $\mathrm{z}$ tysiąca wychodzących

pozostanie stu,

a ze stu wychodzących

pozostanie dziesięciu»

- o domu Izraela. ${ }^{69}$

4. Bo tak rzekł JHWH o domu Izraela:

«Szukajcie mnie, a będziecie żyć!

5. A nie szukajcie Betelu

ani do Gilgal nie pielgrzymujcie,

ani do Beerszeby nie przechodźcie,

bo Gilgal na pewno pójdzie do niewoli

i Betel stanie się miejscem katastrofy!»

6. «Szukajcie JHWH, a będziecie żyć, aby nie wdarł się ogień ${ }^{70}$ do domu Józefa i nie pochłonął [go], a nie ma nikogo, kto by ugasił» - o Betelu. ${ }^{71}$

68 Jak poświadcza G, słowo „Pan” jest późniejszym uzupełnieniem; BHS; H. W. Wolf f, Dodekapropheton 2, s. 269.

69 Wyrażenie stojące na końcu w.3 chętnie przenoszone jest do wprowadzenia słowa JHWH na początku tego wiersza (analogicznie do w. 4; tak BHS; H. W. W o $1 \mathrm{f} \mathrm{f}$, Dodekapropheton 2; E. Z a w i s z e w s k i, Księga Amosa, s. 217), co nie znajduje potwierdzenia w świadectwach tekstowych i wymagałoby wyjaśnienia, jak mogło dojść do takiego nielogicznego przesunięcia. Raczej są to wtórne uzupełnienie; J. J e r e m i a s, Der Prophet Amos, s. 59 przyp. 2.

70 Nie ma powodu do ingerencji w tekst, wbrew BHS i in.; H. W. W olff, Dodekapropheton 2; zob. też HAHAT.

71 Zob. powyższy przypis do w. 3. Wydaje się, że możliwe byłoby również tłumaczenie: „Betel nie ma nikogo, kto by ugasił [go]”; por. G, która jednak ma

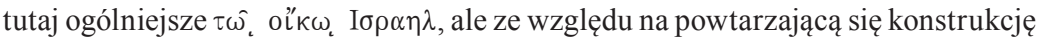
należy wybrać powyższy przekład. Zob. też H. W. W o 1 ff, Dodekapropheton 2. 
7. «Zmieniający ${ }^{72} \mathrm{~W}$ piołun prawo $^{73}$

i sprawiedliwość na ziemię rzucili».

8. Stworzyciel Plejad i Oriona

i zmieniający w poranek śmiertelną ciemność,

a dzień w noc zaciemnia;

wzywający wody morza,

tak że wylewa je na powierzchnię ziemi:

$\mathrm{JHWH}^{74}$ to jego imię!

9. Wyznaczający ${ }^{75}$ spustoszenie przeciwko mocnemu

i spustoszenie przeciwko fortyfikacji «sprowadzi»/ nadejdzie. $^{76}$

10. «Nienawidzą w bramie sprawiedliwie sądzącego i mówiącym całą prawdę ${ }^{77}$ gardzą.

11. Dlatego - ponieważ podnosicie dzierżawę ${ }^{78}$ biedakom

72 Dla dodanie ,biada” nie ma żadnych podstaw tekstowokrytycznych (co dotyczy również G; wbrew BHS); H. W. W o 1 ff, Dodekapropheton 2, s. 269-270.

$73 \mathrm{G}$, która inaczej zrozumiała wiersz, nie może być (mimo Sdz 7,13) podstawą korekty tekstowej; zob. H. W. Wolff, Dodekapropheton 2, s. 269.

${ }^{74}$ Lekcja krótsza przemawia za TM (zob. BHS).

75 Przekaz tekstowy jest niepewny. חל - ,rozświetlić”, „,sprawić, że zabłyśnie”, a przenośnie „rozpogodzić się”, „ucieszyć się” (HAHAT), co mogłoby prowadzić do ujęcia kolejnych rzeczowników jako nazw gwiazd czy gwiazdozbiorów: שר /

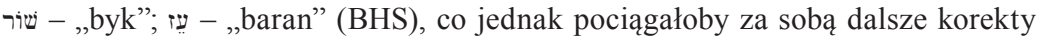

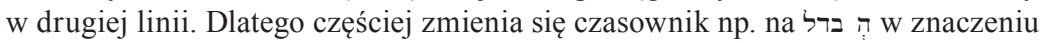
„wyznaczyć”; H. W. W olff, Dodekapropheton 2, s. 270, lub przyjmuje podobne znaczenie dla czasownika w TM; J. J e r e m i a s, Der Prophet Amos, s. 60 przyp. 5. Dosłownie tłumaczy E. Z a w i s z e w s k i, Księga Amosa, s. 221, co jednak tworzy raczej niezrozumiały tekst.

76 סרש zgodnie oddają กุ, a za nimi często komentatorzy: BHS [prb]; E. Z a w i s z e w s k i, Księga Amosa; W. R u d ol p h, Joel, Amos, Obadja, Jona, s. 197; J. J e r e m i a s, Der Prophet Amos, s. 60 przyp. 6, choć TM (q.) nie jest gorszą lekcją; zob. H. W. Wolff, Dodekapropheton 2.

77 Dosłownie: „właściwie”, do powyższego przekładu HAHAT i in., np. H. W. W olf f, Dodekapropheton 2, s. 268.

78 Hapaxlegomenon wywodzony z akadyjskiego i ugaryckiego z metatezą pierwszych spółgłosek tematycznych. Dlatego przyjmuje się nieraz przypadkowe 
i dostawy ${ }^{79}$ zboża bierzecie od nich:

domy z ociosanych kamieni zbudowaliście, ale nie będziecie w nich mieszkać, winnice wspaniała zasadziliście, ale nie będziecie pić z niej wina. 12. Tak, wiem, jak liczne są wasze przestępstwa i jak mocne są wasze grzechy, prześladujący sprawiedliwego, biorący łapówki i ubogich w bramie uciskają. ${ }^{80}$

13. Dlatego rozumny w czasie tym milczy/zamilknie, bo to jest czas zła (nieszczęścia).

14. Szukajcie dobra, a nie zła, abyście żyli (mogli przeżyć) a będzie JHWH, Bóg zastępów z wami tak, jak mówiliście!

15. Nienawidźcie zła, a kochajcie dobro

i ustanówcie w bramie prawo!

Może zmiłuje się (okaże łaskę) JHWH, Bóg zastępów nad resztą Józefa».

16. Dlatego tak rzekł JHWH, Bóg zastępów, Pan: «Na wszystkich placach rytualna żałoba (skarga żałobna) i na wszystkich ulicach mówią: Biada! Biada!, i wzywają rolnika do żałoby i do ${ }^{81}$ rytualnej żałoby znających się na lamencie żałobnym.

podwojenie syczącej i wyprowadza się formę z rdzenia oị - „tratować”; zob. HAHAT; tak np. BHS (prp). Zob. H. W. Wolff, Dodekapropheton 2, s. 270; J. J e r e m i a ss, Der Prophet Amos, s. 60 przyp. 7.

79 Tj. obowiązkowe dostawy jako forma opodatkowania; HAHAT; H. W. W o $1 \mathrm{f} \mathrm{f}$, Dodekapropheton 2, s. 290.

80 Lub eliptycznie: ,pozbawiać prawa” (Am 2,7; Wj 23,2.6 itd.); zob. HAHAT.

81 TM można by tłumaczyć tak jak w G: „do żałoby i rytuału żałobnego, i do znających się na lamencie", ale użycie przyimka אלא, w dwóch różnych znaczeniach, i to obok sg. w acc. (אפר), musi budzić zastrzeżenia. Najprawdopodobniej mamy do czynienia z (pomyłkowym) przestawieniem kolejności słów; tak BHS; 
17. I we wszystkich winnicach rytualna żałoba, bo przejdę przez środek twój» - rzekł JHWH".

Bez trudu można zauważyć, że kompozycja ta nie jest literacko jednolita. Od razu odnotujmy (dalsze uwagi poniżej), że drobnymi dodatkami są apozycje do imienia JHWH, częściowo nieobecne w Septuagincie i zakłócające budowę poematu. Podobnie zbędne są zaburzające rytm konstrukcje z ל na końcu w. 3 i 6 .

Zewnętrzne ramy poematu tworzą skargi żałobne z w. 1-3 i w. 16-17. O ile w 3,1 przemawiał Bóg (pf.), to zgodnie z 5,1 mówi sam prorok (ptp.), a adresatem jest tak samo jak w 5,25 „dom Izraela”, tj. nie tyle lud, ile państwowo zorganizowana społeczność. Treścią (i formą) całego poematu z Am 5-6 (zob. 5,16-17.18; 6,1) ma być qina ${ }^{\mathrm{h}}$, dlatego też typowy rytm $3+2 .^{82}$ Izrael przedstawiony został

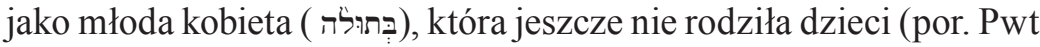
22,23-24). Kończy ona tragicznie w momencie swego największego rozkwitu, choć jeszcze bezdzietna. Wiersz 2 nie precyzuje, co jest powodem jej upadku. A dobór metafory wynika prawdopodobnie z faktu, że miasta (w hebr. w rodzaju żeńskim), zwłaszcza stolice, chętnie były przedstawiane jako kobieta (np. Iz 1,21). ${ }^{83}$ Co więcej, nikt już nie może jej pomóc. ${ }^{84}$ Skarga proroka znajduje uzasadnienie w Bożym słowie (w. 3), które zapowiada militarną katastrofę (por. np. 3,11; 4,3): oddziały wojskowe królestwa Izraela zostaną przez wrogów zdziesiątkowane (por. 3,12 ) ${ }^{85}$ Dlatego żałobny lament

H. W. W o $1 \mathrm{ff}$, Dodekapropheton 2, s. 271; J. J e r e m i a s, Der Prophet Amos, s. 61 przyp. 8 (który za alternatywne wyjaśnienie TM uważa hypallage, ale istnienie takiej figury stylistycznej w biblijnym hebrajskim jest w najlepszym razie niepewne).

${ }^{82}$ Skarga żałobna; zob. W. R u d o 1 p h, Joel, Amos, Obadja, Jona, s. 187-188; J. J e r e m i a s, Der Prophet Amos, s. 62.

83 Zob. A. Fitzger a ld, BTWLT and BT as Titles for Capital Cities, CBQ 37(1975) 2, s. 167-183.

${ }^{84}$ J. J e r e m i a s, Der Prophet Amos, s. 64, sądzi, że chodzi o brak lekarstwa, tak że ,panna” umiera w młodości i bezdzietnie.

${ }^{85}$ Dlatego bardzo wątpliwe, by w reszcie, która pozostała, można by się doszukiwać pocieszenia, jak chciałby E. Z a w i s z e w s k i, Księga Amosa, s. 217. Wymordowanie czy śmierć $90 \%$ populacji jest niewyobrażalną katastrofą (nieco inaczej w 5,15, ale z późniejszej perspektywy; zob. poniżej). Do problemu „reszty” 
„biada!” rozlega się w całym mieście, na każdym placu i ulicy, a nawet na polach wokół miasta (w. 16) czy w winnicach (w. 17), mimo że winnice kojarzone były z radością (por. Sdz 21,20-21; Iz 32,12). Ostatecznym powodem nieszczęścia jest fakt, że Bóg przejdzie przez ) (עבר ב Izrael jak w czasie Paschy przez Egipt (Wj 12,12) i nie już więcej go nie ominie ( עבר ל - zob. 7,7; 8,2; por. Wj 12,23). JHWH zwrócił się przeciwko Izraelowi.

Wewnętrzne ramy tworzą wezwania do szukania Boga i dobra (w. 4-6 i 14-15). W w. 4-6, których pierwsza część jest mową JHWH (w. 4-5), szukanie Boga stoi w opozycji do pielgrzymowania do Betel i Gilgal (por. 4,4-5). Czasownik דרש oznacza dążenie do czegoś oraz pielgrzymowanie do świątyni czy miejsc świętych, które były miejscami Bożej bliskości i gdzie można było Boga wychwalać, pytać (za pośrednictwem proroków), a przede wszystkim prosić Go o pomoc. ${ }^{86}$ „Szukać Boga” oznacza więc „zwracać się do niego w potrzebie”, co jednak nie jest już dłużej tożsame z pielgrzymowaniem do izraelskich świątyń! Betel nie wiąże się już z niczym innym, jak tylko $z$ katastrofą. Zasadne staje się więc pytanie, czy istniała jeszcze jakaś nadzieja na ratunek. Bo gdzie, jeśli nie w świątyni, miano prosić Boga o ocalenie? Przytoczone przez proroka Boże napomnienie jawi się jako paradoksalne. To, na czym dotychczas polegało szukanie Boga, stało się jego zaprzeczeniem i przegraną szansą na przeżycie.

W obecnej postaci tekstu również w. 4-6 mają ramową budowę z wezwaniem do szukania Boga w w. 4 i 6, otaczającym odradzanie pielgrzymowania do miejsc świętych. Jednak przejście z mowy JHWH do słów o JHWH w 3. osobie, koncentracja jedynie na Betel (por. 3,14; Oz 6,10; 1Krl 12,26-30; 13,32) wskazują, że w. 6 jest komentującym rozszerzeniem (w duchu deuteronomistycznym?), które czyni z Bożego napomnienia ostateczne prorockie ostrzeżenie. ${ }^{87}$

w literaturze prorockiej W. H. S c h m i d t, Wprowadzenie do Starego Testamentu, s. 162.

86 Zob. G. G e r l e m a n, E. R u p r e c h t, דרש, w: THAT I, s. 460-467.

87 Tak też H. W. W o 1 ff, Dodekapropheton 2, s. 271, 276, 282; J. J e r e m i a s, Der Prophet Amos, s. 67, którzy zwracają uwagę na związki z 4,6-13. 
W przeciwnym razie ogień pochłonie „dom Józefa” (w 5,15 mowa jest o „reszcie Józefa”). Motyw ognia zdaje się pochodzić z mów przeciwko narodom 1,4.7.14; 2,2 i z drugiej wizji 7,4-6. Dodatkiem jest też wzmianka o Beerszebie, miejscowości granicznej południowej Judy - jak sugeruje 8,14 miałyby tam być czczone inne bóstwa ${ }^{88}$ W zamyśle redaktora bałwochwalstwo miałoby obejmować całość Izraela i Judę, sięgając od północnych krańców Izraela (Dan) po południowe granice Judy (Beerszeba; por. Sdz 20,1).

Druga część ram wewnętrznych (w. 14-15) nie mówi o szukaniu Boga, lecz dobra w opozycji do zła. Drogą do ewentualnego ocalenia nie jest szukanie obecności Boga w miejscach świętych, w nabożeństwie, kulcie, lecz działanie na rzecz bliźniego, ku jego dobru i unikanie zła (antonimy „,dobro” i ,zło” oraz „kochać” i „nienawidzić”). ${ }^{89}$ W szczególności chodzi o sprawiedliwe stanowienie prawa, rozstrzyganie sporów sądowych w bramie (brama była m. in. miejscem sporów sądowych; ${ }^{90}$ zob. w. 7-13*). Tylko wtedy możliwy będzie kontakt z Bogiem, Jego stała obecność, o której są niesłusznie przekonani adresaci, i byłaby szansa na to, że Bóg jeszcze zmiłuje się nad resztą swojego ludu. Zwraca uwagę, jak wątła jest ta nadzieja, która tylko „może” ( אוּלַ) dotyczyć, i to jedynie ,reszty Józefa” (unikanie określenia Izrael?). Nie ma więc już możliwości uniknięcia katastrofy, a jedynie ocalenia reszty. Mowa o reszcie zakłada, że nieszczęścia spadły już na lud (por. 5,3). Być może jest jeszcze jednak ostatnia szansa na przetrwanie reszty. Wydaje się zatem, że nie jest to już

88 Zob. poniżej i H. W. Wolff, Dodekapropheton 2, s. 372, 380-382; J. J e r e m i a s, Der Prophet Amos, s. 114.120-122; inaczej np. W. R u d o 1 p h, Joel, Amos, Obadja, Jona, s. 191, ale wskazanie na 1Krl 19,3 jako dowód na zwyczaj pielgrzymowania z północnego Izraela jest bardzo nieprzekonujący - Eliasz uciekł tak daleko, jak to tylko możliwe, na skraj zamieszkałego obszaru.

${ }^{89}$ Dobro i zło pojmować trzeba tutaj w najogólniejszym i nieskomplikowanym sensie; zob. H. J. S t o e b e, שוב, w: THAT I, s. 652-664; t e n ż e, רעע, w: THAT II, s. $794-803$.

90 Np. Hi 29,7nn.; zob. H. J. B o e c k e r, Recht und Gesetz im Alten Testament und im Alten Orient, Neukirchen-Vlyun 19842, s. 22-25, 54-55. 
przesłanie samego Amosa, a raczej jego uczniów czy tradentów, którzy nie ważyli się na wypowiedź o oczekiwaniu wspaniałego ocalenia. $^{91}$

Choć w TM w środku kompozycji stoi hymniczny fragment (w. 8-9), to ze względu na jego wtórność (zob. poniżej) na wcześniejszym etapie historii redakcji środkową część tworzyły w. 7.10-13*, będące wykazem win, naganą (Scheltrede). Adresaci piętnowani są za nieprawości, odrzucenie prawa i sprawiedliwości. Ta para pojęć (por. 5,24 ) odnosi się zarówno do konkretnych czynów, oznaczając właściwe rozstrzyganie sporów i troskę o innych członków społeczności, przede wszystkim ubogich, jak i w ogólniejszym sensie, wskazując na harmonijnie toczące się życie społeczne. ${ }^{92}$ Zostały jednak przekształcone w swoje przeciwieństwo - w szkodliwy piołun, a potem porzucone (w. 7). Kolejne wiersze ukazują konkretnie szerzące się zło: w sądzie odrzuca się tych, którzy sprawiedliwie sądzą (w. 10b: sędziowie) i uczciwie mówią (w.10b: świadkowie?); wyzyskuje się ekonomicznie biedaków, żądając od nich coraz wyższych danin (w. 11a $\alpha),{ }^{93}$ by samemu cieszyć się luksusem (w. 11aß-b: domy z ociosanych kamieni, które przypominają pałace, i drogocenne winnice). Oskarżenie przechodzi od razu w groźbę (Drohwort) - wyzyskiwacze nie będą korzystać ze swoich pałaców i winnic. Bożej uwadze nie uchodzi bowiem ogrom ich przestępstw (w. 12a). Na zakończenie (oskarżenie) jeszcze raz podkreśla się, że biedacy i niewinni nie mogą dochodzić swoich praw w sądzie (bramie), bo wszędzie panuje przekupstwo i uciskanie pokrzywdzonych (w. 12b). Wiersz 11, mówiący o ekonomicznym wyzysku ubogich, otaczają w. 10 i 12 koncentrujące się na nieprawościach sądowych (ramowa funkcja motywu bramy). Ponadto w. 11 wprowadzony jest nieco zaskakującym złożeniem

91 Zob. J. J e r e m i a s, Der Prophet Amos, s. 72-73.

92 Zob. powyżej. Wg J. Jeremiasa, prawo i sprawiedliwość to wielkości dane przez Boga Izraelowi, które ten korumpuje; tamże, s. 67-68.

93 Ze względu na całkowicie inną terminologię tłem oskarżenia o obowiązkowe „dostawy zboża” nie może być, jak chciałby W. R u d o l p h, Joel, Amos, Obadja, Jona, s. 198, zakaz lichwy (Wj 22,24; Kpł 25,36.). 
לכֵן יֵַַן, tak że trudno oprzeć się wrażeniu, że mamy do czynienia $\mathrm{z}$ połączeniem pierwotnie niezależnych jednostek tekstowych ${ }^{94} \mathrm{za}$ pomocą לכיבן. Tak czy inaczej wiersze te przynoszą ostre oskarżenie o całkowite zniszczenie porządku społecznego i wyzysk, chciwość i brak praworządności.

Wiersz 13, także wprowadzony przez לבין, zawiera zaskakującą, mądrościową myśl: w złym czasie, okresie nieszczęścia roztropny się milczy - z pewnością nie może chodzić o Amosa, który przecież (roztropnie) nie milczał. Jest to więc refleksja późniejszych redaktorów. ${ }^{95}$ Identyczne wyrażeni: „bo to czas zły”, występuje jeszcze w Mi 2,3 (po którym w w. 4 stoją słowa: „w tym dniu” - zob. poniżej), gdzie określenie takie zdaje się odnosić się do upadku Judy i wygnania babilońskiego. ${ }^{96}$

Centralnie umieszczony hymn (w. 8-9) ku czci Stworzyciela ciał niebieskich (co może implikować krytykę babilońskich kultów astralnych - por. 5,26), który może zniszczyć świat (w. 8: światłość i dzień przekształca w ciemność, nieszczęście, a ziemię zalewa wodą, co jest niczym innych jak odwróceniem aktów stwórczych) ${ }^{97}$ i spowodować upadek możnych władców (w. 9), choćby ukryli się za swoimi murami i umocnieniami, jest doksologią (sądową).${ }^{98}$ Bóg opiewany jest jako

94 Zob. J. J e re m i a s, Der Prophet Amos, s. 70, według którego w. 11 jest retoryczną całością.

95 H. W. Wolff, Dodekapropheton 2, s. 275; J. J e re m i a s, Der Prophet Amos, s. 70.

96 Nawet jeśli wyrażenia: „to jest czas nieszczęścia” i „w tym dniu” miałyby być w tych wierszach z Mi wtórnie dodane (tak H. W. W o $1 \mathrm{ff}$, Dodekapropheton 4: Micha, BK XIV/4, Neukirchen-Vluyn 1982, s. 39-40). Notabene zostały one w Mi użyte w kontekście oskarżenia o nieprawość i skargi żałobnej.

97 Zob. Rdz 1,3-5.6-10; por. też Rdz 7,10nn., choć nie jest to jedyna możliwa interpretacja użytych tutaj wyobrażeń. Do różnych prób interpretacji tego hymnu imiesłowowego (o gatunku F. C r ü s e m a n n, Studien zur Formgeschichte von Hymnus und Danklied in Israel ) zob. komentarze, np. H. W. Wolff, Dodekapropheton 2, s. 282-283; J. J e r e m i a s, Der Prophet Amos, s. 68-69.

98 Pojęcie zapożyczone od: G. v o n R a d, Teologia Starego Testamentu, Warszawa 1986, s. 270, 281-282. 
ten, który sprawiedliwie karze władców i bogaczy, a jego kontekstem są oskarżenia z w.7.10.11-12.99

\section{Ostatnia wizja $(9,1-4)$}

Mimo że w tym fragmencie ,prorok” nie wypowiada się wprost krytycznie o kulcie, to jest omawiany w niniejszym artykule $\mathrm{z}$ tego powodu, że Bóg pojawia się w nim jako stojący na ołtarzu. Rodzi się pytanie o to, jak postrzegana jest w nim świątynia i kult. Jego interpretację utrudniają problemy tekstowe.

„1. Ujrzałem Pana stającego na ołtarzu i rzekł:

«Uderzę» ${ }^{100}$ wierzch kolumny ${ }^{101}$ i zadrżą progi,

«i odetnę ich wszystkich (od życia) w drżeniu (przez

trzęsienie)», ${ }^{102}$

a ich resztę mieczem zabiję.

99 Do hymnicznych partii w Am zdaje się nawiązywać również 1,2: „JHWH z Syjonu ryczy i z Jerozolimy wydaje swój głos...”, który jest powygnaniowym rozszerzeniem, spinającym wraz z innymi hymnami Am aż po 9,5-6; J. J e r e $m$ i a s, Der Prophet Amos, s. 3-4).

${ }^{100}$ W TM impt.: „uderz”, który musiałby być skierowany do proroka, ale w jaki sposób człowiek miałby wprawić w drżenie kolumnowe ramy bramy świątyni?; E. Z a w i s z e w s k i, Księga Amosa, s. 249, nie dostrzega w tym żadnej trudności. Powszechnie przyjmuje się, że tekst jest uszkodzony, a korekty idą czasami bardzo daleko. Nie ma żadnego powodu ani poświadczenia tekstowego, by przenosić jak chcieliby BHS; H. W. W ol ff, Dodekapropheton 2, s. 385-386, co i tak zmuszałoby do korekt kolejnych czasowników. Lepiej poprawić impt. na 1. os. impf.; tak J. J e r e m i a s, Der Prophet Amos, s. 122 przyp. 1, podobnie W. R u d o l p h, Joel, Amos, Obadja, Jona, s. 241, z tym że dodaje jeszcze inf. (emfatyczny).

${ }^{101}$ Do znaczenia tego wyrazu HAHAT; lekcja $\mathrm{G}$ jest prawdopodobnie wynikiem pomyłki tłumacza; zob. H. W. W o $1 \mathrm{ff}$, Dodekapropheton 2, s. 386.

${ }^{102}$ TM jest z pewnością uszkodzony: „, obetnij ich za głowę ich wszystkich”. Ponieważ świadectwa tekstowe zasadniczo poświadczają TM, jesteśmy skazani na spekulacje co do jego sensu; zob. BHS i komentarze: W. R u d o l p h, Joel, Amos, Obadja, Jona, s. 241-242, który zasadnie podważa zwyczajowe tłumaczenie, jakie można spotkać np. w E. Z a w i s ze w s k i, Księga Amosa; H. W. W olff, Dodekapropheton 2, s. 386; J. J e r e m i a s, Der Prophet Amos, s. 122 przyp. 2. Powyżej oddano czasownik בצע w 1. os. impf. w znaczeniu przecinania linii życia 
Nie ucieknie spośród was żaden uciekający i nie zostanie ocalony spośród was żaden zbieg.

2. Jeśli przebiją się do szeolu, stamtąd ręka moja wyciągnie (...)

4b. I skieruję moje oczy na nich

ku złu (nieszczęściu), a nie ku dobru (powodzeniu)".

Piąta wizja uchodzi za późniejszy dodatek, gdyż mocno różni się o cyklu czterech wizji z 7,1-8,2*: poza informacją o tym, co ,ja”-wizjoner zobaczył, i słowami Pana nie ma żadnego innego elementu formalnego typowego dla wcześniejszych wizji. Co więcej, tematem wizji nie jest możliwość lub brak możliwości okazania litości Izraelowi. Jednak fakt, że wraz z wizjami otaczające środkową części Am 3-6* wyrocznie przeciwko narodom z Am 1-2* zbudowane są z pięciu części czy strof (wyrocznie przeciwko Tyrowi 1,9-10, Edomowi 1,11-12 i Judzie 2,4-5 jest późniejszym rozszerzeniami), sugeruje, iż kompozycja wizji też składała się z pięciu wizji, co jeszcze nie rozstrzyga o pochodzeniu (datowaniu) całej kompozycji ostatniej wizji. Stoi ona naprzeciwko wyroczni przeciwko Izraelowi z 2,6-16*, która podobnie jak piąta wizja różni się od poprzednich i jest czymś w rodzaju punktu kulminacyjnego. ${ }^{103}$ Wizje i ich kompozycja są refleksją nad misją Amosa, a nie zwykłą relacją o prorockim przeżyciu.

Ostatnia wizja nawiązuje do trzeciej („Pan stający na/nad”) i rozwija temat czwartej - koniec Izraela. Uderzenie w zwieńczenie kolumn(y) świątyni powoduje drżenie progów, w których osadzone są wrota (por. Iz 6,4) ${ }^{104}$, a wraz ze świątynią drży cały Izrael, a nawet

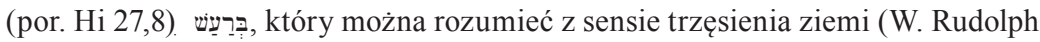
i zob. Am 1,1).

${ }^{103}$ J. J e r e m i a s, Völkersprüche und Visionsberichte im Amosbuch, w: t e n ż e, Hosea und Amos, s. 157-171;t e n ż e, Der Prophet Amos, s. 7-11,123-124. O wtórnych rozszerzeniach w Am 1,3-16 ponadto tamże, s. 16-17, 26, 28-29 (i s. 24); H. W. W o 1 f f, Dodekapropheton 2, s. 170-173,184-185.

${ }^{104}$ Do tego H. W. Wolff, Dodekapropheton 2, s. 389-390; J. J e r e m i a s, Der Prophet Amos, s. 124-125, zakładając, że świątynia jerozolimska z Iz 6 może przypominać tą z 5. wizji (w Betelu?); por. też 1Krl 6-8. Jeśli rekonstrukcja tekstu 
kosmos (na co mogą wskazywać kolejne wiersze). Słowa Pana mają najwyraźniej klamrową konstrukcję (zwłaszcza jeśli powyższe rozstrzygnięcia tekstowo-krytyczne są słuszne) wyznaczoną przez Boże „ja”. Drżenie świątyni prowadzi do zagłady Izraela, a ci, którym uda się ocaleć z tego trzęsienia (ziemi), też zostaną zabici, i to mieczem $(9,1 a \gamma+4 a)$. Nikt nie umknie Bożej karze (9,1b-4a). Wymieniono pięć obszarów, które nie mogą stanowić schronienia przed Bogiem, w górze i w dole: świat podziemny / niebo / szczyt Karmelu / dno morskie / więzienie. Bóg posłuży się nie tylko mieczem, ale i mocami chaosu wężem. Katastrofa, która czeka Izraela, to nie tylko wygnanie (por. 5,27; 6,7; 7,11.17), gdyż wszyscy poniosą śmierć, a reszta zginie, jak zdaje się wskazywać miecz, na wojnie. Bóg skieruje swój wzrok na Izraelitów, ale nie dla ich ocalenia (,dobra”), lecz ku ich nieszczęściu (,złu”), co jest nawiązaniem do 5,14-15. Tym samym kara (zło) odpowiada winie (złu) Izraela. ${ }^{105}$

\section{Zagłada miejsc świętych (wpływ Księgi Ozeasza)}

W słowie przeciwko Izraelowi z 2,6-16*, umieszczonym wśród wyroczni przeciwko narodom w Am 1-2 i będącym mową Bożą, pojawia się motyw znany z Księgi Ozeasza: ucztowanie przy ołtarzu w domu Bożym, tj. świątyni - 2,8:

„I na ubraniach wziętych w zastaw wyciągają się ${ }^{106}$ koło każdego ołtarza,

jest właściwa, to może chodzić o trzęsienie ziemi (tak też H. W. Wolff, Dodekapropheton 2, s.378 i 390), ale wtedy zaskakujące byłoby powiązanie z militarną klęską. Z kolei E. E. Z a w i s z e w s k i, Księga Amosa, s. 230, uważa, że symbolika wizji przywodzi na myśl czyn Samsona z Sdz 16,26-30.

${ }^{105}$ Zob. J. J e r e m i a s, Der Prophet Amos, s. 124-127, który ponadto uważa 9,4b za zamknięcie najstarszej postaci Am; tak też H. W. W o $1 \mathrm{f} \mathrm{f,Dodekapropheton} \mathrm{2,}$ s. 393-394,396-398,404-406.

${ }^{106}$ Czasownik דִ נטה poza omawianym miejscem zawsze występuje w znaczeniu przechodnim (,rozciągać coś”), dlatego często skreśla się przyimek (powołując się na G, która jednak zupełnie inaczej oddaje sens pierwszej linii); BHS; H. W. W o $1 \mathrm{fff}$, Dodekapropheton 2, s. 163, który niszczy przy tym poetycką strukturę wiersza 
i wino z odszkodowania piją w domu ich Boga". ${ }^{107}$

Umiejscowienie haniebnych czynów w miejscach świętych (ołtarze i świątynia, przy czym może, ale nie musi chodzić o określenie jednego i tego samego miejsca) pokazuje, że zarzut ze zwiastowania Amosa przeciwko luksusowi uczestników kultu pochodzącemu z wyzysku ubogich (zob. powyżej) został połączony w motywami zdającymi się wywodzić z Oz (4,7nn.; 8,11-13; 10,1-2; zob. też 9,8), a tym samym okazuje się w tórnym zabiegiem redakcyjnym. ${ }^{108}$ Wylegują się oni na ubraniach wziętych od ubogich w zastaw (por. Wj 22,25; Pwt 24,12-13.17) i ucztują, pijąc wino uzyskane jako lub raczej za środki z odszkodowania, które miało służyć zadośćuczynieniu poszkodowanemu, przede wszystkim pokrzywdzonym kobietom (Wj 21,22; Pwt 22,19) lub zostało wymuszone w nieuczciwym postępowaniu sądowym (por. w. 6-7 i Prz 17,26) ${ }^{109}$ Oskarżenia o charakterze społecznym zostały poszerzone o zarzut skierowany przeciwko kultowi, gdyż uroczystości kultowe służą jedynie korzystaniu z bogactwa uzyskanego w niegodziwy sposób. ${ }^{110}$

$(3+3)$. Jednak wyjątkowa konstrukcja wydaje się zamierzona, gdyż ten sam czasownik w sensie „łamać”, „naruszać (czyjeś) prawo” pojawia się w w.7aß; zob. J. J e r e m i a s, Der Prophet Amos, s. 19 przyp. 4 oraz HAL i HAHAT.

${ }^{107}$ Może chodzić zarówno o jednego Boga, jak i o wielu bogów, jedną lub wiele świątyń; zob. W. R u d ol p h, Joel, Amos, Obadja, Jona, s. 139, tłumaczy ostatecznie „domy Boże”. Nie żadnego powodu, by zakładać, że musi chodzić o świątynię innych bogów, jak chciałby E. Z a w i s z e w s k i, Księga Amosa, s. 198, a nie JHWH - tak też tłumaczą H. W. W o 1 ff, Dodekapropheton 2, s. 160; J. J e r e m i a s, Der Prophet Amos, s. 19. U Am nigdy więcej nie spotykamy wyrażenia „dom Boży (JHWH)”.

${ }^{108}$ Tamże, s. 23-24; zob. też H. W. W o 1 f f, Dodekapropheton 2, s. 163. „Ołtarze” w pl. spotykamy w Am jeszcze tylko w 3,14 (zob. poniżej), a w sg. (poza 3,14, gdzie mowa jest również o „rogach ołtarza/ołtarzy”) w piątej wizji (9,1; zob. powyżej). Do „domu Bożego” zob. poprzedni przypis.

${ }^{109}$ Do znaczenia ענש (ptp. pass.) zob. HAHAT i H. W. W o 1 f f, Dodekapropheton 2, s. 203; J. J e r e m i a s, Der Prophet Amos, s. 23; Inaczej np. D. R. H i 11 e r s, Palmyrene Aramaic inscriptions and the Old Testament, especially Amos 2:8, Zeitschrift für Althebraistik 8/1995, s. 58-62 (wino ze środków jakiegoś kultowego stowarzyszenia).

${ }^{110}$ Jeszcze późniejszy jest dodatek z 2,7b $\beta$, w którym ucisk ubogich i seksualne wykorzystywanie kobiet społecznie uzależnionych od bogaczy zostały 
Z Oz związana jest prawdopodobnie groźba z 7,9:

„Wtedy zostaną spustoszone wyżyny Izaaka

i świątynie ${ }^{111}$ Izraela zostaną zniszczone, ${ }^{112}$

i powstanę przeciwko domowi Jeroboama z mieczem".

Wiersz ten jest pomostem między trzecią wizją Amosa (7,7-8) a narracją o zakazie dla Amosa przemawiania w Betel i sporze z kapłanem Amazjaszem (7,10-17). ${ }^{113}$ Cykl czterech, kunsztownie zbudowanych wizji Amosa (7,1-8*; 8,1-2*) demonstruje przejście od dającego się jeszcze odwrócić w pierwszej i drugiej do bezwarunkowego sądu Bożego w trzeciej i czwartej wizji. Między drugą parę wizji został wstawiony jedyny (dłuższy) tekst narracyjny. Opowiadanie z 7,10-17 ma dodatkowo uzasadniać, dlaczego Amos zamilkł, porzucając wstawiennictwo za Izraelem z dwóch pierwszych wizji. ${ }^{114}$ Am 7,9 dołącza się do trzeciej wizji, w której Bóg zapowiada, że już więcej nie ominie Izraela, ocalając go ( עבר ל nawiązuje do opisu Paschy z Wj) ${ }^{115}$. Cierpliwość Boga się skończyła. Nie ma tutaj miejsca na szczegółową analizę tej wizji, która wbrew rozpowszechnionemu przekonaniu najprawdopodobniej nie mówi o pionie z ołowiu, ${ }^{116} \mathrm{lecz}$

zakwalifikowane za pomocą Ezechielowego wyrażenia jako zbezczeszczenie świętego imienia Bożego (por. Ez 36,20; 39,7; też 20,3; 22,2.32); zob. J. J e r e m i a s, Der Prophet Amos, s. 24. Zaś H. W. W o $1 \mathrm{ff}$, Dodekapropheton 2, również to oskarżenie kojarzy z Oz $(4,14)$, a końcowe wyrażenie z Kodeksem świętości (np. Kpł 20,3).

${ }_{111} \mathrm{Tj}$. miejsca święte ze wszystkimi przynależnymi do niego urządzeniami (HAHAT).

112 ח 112 - „leżeć w gruzach”, „być spustoszonym” (podczas gdy חרב „wyschnąć”, „być wysuszonym”; oba rdzenie mają pasywne znaczenie; zob. HAHAT).

${ }^{113}$ Zob. też H. W. W o 1 f f, Dodekapropheton 2, s. 340-341.

114 Szczegóły w J. J e r e m i a s, Der Prophet Amos, s. 94-108, przy czym trzeba zauważyć, że zarówno cykl wizji, jak i narracja nie pochodzą od samego proroka.

115 Zob. tamże, s. 73.

116 Tak np. H. W. Wolff, Dodekapropheton 2, s. 346-347. Także tłumacząc jako „ołów”, ma się nieraz na myśli jakimś rodzaj broni; zob. W. R u d o l p h, Joel, Amos, Obadja, Jona, s. 234-236. Z kolei E. Z a w i s z e w s k i, Księga Amosa, 237-238, sądzi, że mowa jest o płynnym ołowiu jako narzędziu kary (nie pisze o tym 
o cynie, wartościowym metalu będącym składnikiem brązu. ${ }^{117}$ Pan stoi na murze z cyną w ręką, tj. bronią $(7,7)$ i sam stanie się śmiertelnym orężem wymierzonym w Izraela $(7,8)$. Zarówno do trzeciej, jak i do czwartej wizji (por. 8,3) dołączono zapowiedzi konkretnych katastrof. Am 7,9 przejmuje z 7,7-8 motyw broni, zaś „,miecz” z 7,11, ${ }^{118}$ który miał zadać śmierć Jeroboamowi. Jednak w 7,9 wymierzony zostaje w „dom”, tj. dynastia Jeroboama. Wiersz ten pochodzi zatem przypuszczalnie z okresu po spokojnej śmierci samego króla Jeroboama II. Zamiast o Betel (por. 7,13) mowa jest o „świątyniach Izraela”, a zamiast o „domu Izaaka” (por. 7,16) - o „wyżynach Izaaka”. Łącząc cykl wizji z narracją o prorokowaniu w Betel i Amazjaszu, interpretuje je w duchu Księgi Ozeasza: kult na wzgórzach (Oz 4,13-14) i w świątyniach (Oz 8,4-13; 10,4-8; por. też wyrocznia przeciwko „domowi” Jehu w Oz 1,4). Nawiązując zatem do Księgi Ozeasza, zapowiada koniec wszelkiego rodzaju instalacji kultowych - wyżyn i świątyń (wyżyny to być może lokalne miejsca święte, podczas gdy świątynie związane były w kultem państwowym) ${ }^{119}$ oraz dynastii królów izraelskich.

\section{Po upadku Jerozolimy}

Krytyka porządków w Judzie

Wyrocznia przeciwko Izraelowi z 2,6-16* poprzedzona została wyrocznią przeciwko Judzie $(2,4-5)$, która jawi się jako młodsze uzupełnienie.

„Tak rzekł JHWH:

$\mathrm{Z}$ powodu trzech przestępstw Judy

wprost, ale miałby być wlewany do gardła karanej kobiety; jednak przynajmniej w Starym Testamencie nie znajduje na to potwierdzenia).

117 Do wywodzącego się z akadyjskiego ș oraz poetyckiej budowy (z grą słów) i znaczenia tej wizji J. J e re m i a s, Der Prophet Amos, s. 101-103 i podana tam literatura.

${ }^{118}$ Imię Izaak pojawia się w Am jeszcze jedynie w 7,16.

119 Tak J. J e r e m i a s, Der Prophet Amos, s. 112. 
i z powodu czterech nie odwrócę, z powodu odrzucenia przez nich Tory JHWH i praw jego nie przestrzegali, tak że zwodzą ich kłamstwa (bóstwa), ${ }^{120}$ za którymi chodzili (już) ich ojcowie; wyślę więc ogień przeciwko Judzie i pochłonie pałace Jerozolimy".

Inaczej niż w starszych tekstach Księgi Amosa winą Judy i Jerozolimy nie są przestępstwa przeciwko ubogim i stojącym niżej w hierarchii społecznej, lecz nieprzestrzeganie Tory JHWH (późne określenie w liczbie pojedynczej), na którą składają się prawa (w liczbie mnogiej). ${ }^{121}$ Choć Tora zawiera też przykazania dotyczące stosunku do bliźniego i ubogiego, to tutaj z jej nieprzestrzegania wynika (impf. cons.) chodzenie za kłamstwami, czyli bóstwami, na wzór swoich przodków, „ojców” Judejczyków. „Chodzić za” oznacza tu uczestniczyć w kulcie obcych bogów, ${ }^{122}$ oddawać się im w posłuszeństwie i czcić ich. Juda oskarżana jest więc o przestępstwa religijne, a nie społeczne. Wiersze te interpretują upadek Judy wraz z Jerozolimą jako następstwo religijnej niewierności Bogu JHWH, posługując się przy tym językiem deuteronomistycznym (por. $2 \mathrm{Krl} \mathrm{17,13-15).}{ }^{123}$

\section{Nauka płynąca z losu Izraela}

Zniszczenie ołtarzy w Betel wspominane jest jeszcze w napomnieniu (Mahnwort) z 3,13-14:

${ }^{120}$ Rzeczowo słusznie G i V mają tutaj lekcję „bogowie”, rzeczownik כִּזִ jest epitetem obcych bogów; HAHAT; podobnie komentarze, np. E. Z a w i s z e w s k i, Księga Amosa, s. 194; H. W. W o 1 f f, Dodekapropheton 2, s. 163.

${ }^{121}$ Tamże, s. 199 (konstrukcja deuteronomistyczna); J. J e r e m i a s, Der Prophet Amos, s. 28 (spisane prawa); zob. też G. L i e d k e, C. P e t e r s e n, תוזרה, w: THAT II, s. $1038-1042$.

122 Wyrażenie takie może pochodzić z określenia pielgrzymki; G. S a u e r, הלך, w: THAT I, s. 491.

${ }^{123}$ J. J e r e m i a s, Der Prophet Amos, s. 27-28; zob. też H. W. W o 1 ff, Dodekapropheton 2, s. 198-199. 
„Słuchajcie i ostrzegajcie ${ }^{124}$ dom Jakuba

- wyrocznia Pana, JHWH, Boga zastępów -

że w dniu pomsty mojej za przestępstwa domu Izraela

na nim

wywrę pomstę na ołtarzach Betelu,

tak że zostaną odrąbane rogi ołtarza,

i upadną na ziemię!"

Wyrocznia ta jest rozszerzeniem kompozycji 3,9-4,3*, składającej się z trzech morfokrytycznie i tematycznie różnych mów skierowanych przeciwko stolicy Izraela i jej elitom; ${ }^{125} \mathrm{~W}$ pierwszej wzywa się świadków, by zaświadczyli o nieprawości w Samarii (3,9-11); druga, oparta na ironicznym porównaniu (pasterz ,ratujący” z paszczy lwa kości strzałkowe i płatek małżowiny usznej), zapowiada zagładę właścicieli bogatych domów $(3,12+15)$; a trzecia skierowana jest przeciwko bogatym kobietom (4,1-3). Dodana w środek drugiej mowy wyrocznia (z rozbudowaną o apozycje formułą ,wyrocznia JHWH”) nie jest zapowiedzią nieuniknionej zagłady bogatych mieszkańców Samarii, lecz wezwaniem jakiejś nieznanej grupy do tego, by ostrzegała „dom Jakuba”. Podobnie jak w 9,7-10 „dom Jakuba” stoi obok „domu Izraela”, gdzie „dom Izraela” odnosi się do królestwa północnego, które zostało przez Boga przesiane $(9,9),{ }^{126}$ co oznacza, że spełniły się zapowiedzi Amosa. Zaś „,domem Jakuba” w rozdz. 9 jest oczyszczony lud, który ocalał z tej katastrofy, powygnaniowa społeczność (niekoniecznie ograniczona do wygnańców). ${ }^{127}$ Związek 3,13-14 z 9,7-10 jest wyraźny. Zaś samo imię „Jakub” jest w Księdze

${ }^{124}$ Można by również tłumaczyć „świadczyć przeciwko” (tak E. Z a w i s z e w s k i, Księga Amosa, s. 208) lub „uroczyście zapewniać” (kogoś; zob. HAHAT), ale ze względu treść mowy najlepsze znaczenie to „ostrzegać” (zwł. J. J e r e m i a s, Der Prophet Amos, s. 43).

${ }^{125}$ Tamże, s. 38-39, 42-44.

${ }^{126}$ Jak zauważyli W. R u d o 1 p h, Joel, Amos, Obadja, Jona, s. 271 i J. J e r e m i a s, Der Prophet Amos, s. 133, wyrażenie „wśród wszystkich narodów” jest dodatkiem naruszającym budowę poetycką wiersza, za pomocą którego redaktor zaznaczył, że ocalonymi są tylko wygnańcy.

${ }^{127}$ Zob. tami̇e. 
Amosa określeniem ludu Izraela, którego czeka zagłada $(7,2.5) .{ }^{128} \mathrm{Na}-$ pomnienie z 3,13-14 każe przysłuchać się przesłaniu Amosa o Bożej pomście (występujący tu 2 razy czasownik pojawia się jeszcze w 3,2) na Izraelu i Betel, o zniszczeniu, o którym mówi piąta wizja z 9,1-4, oraz przestrzegać powygnaniową społeczność przed kroczeniem drogą „domu Izraela”, królestwa północnego - obciążaniem się winą „królestwa grzesznego” $(9,8)$ i „wszystkich grzeszników ludu” Bożego $(9,10)$, czyli przed zadufaniem w możliwości organizacji państwowej i niesprawiedliwością społeczną.

Nie do końca jasne są wiersze 8,13-14, będące częścią literacko złożonej i w całości wtórnej kompozycji 8,3-14, która jest głównie interpretacją czwartej wizji $(8,1-2)$ i mozaiką cytatów ze starszych perykop Księgi Amosa. ${ }^{129}$ Problematyczne jest nie tylko datowanie (i osadzenie w procesie powstawiania księgi), ale i znaczenie wielu słów, które zdają się krytyką bałwochwalstwa, niewierności wobec JHWH. Już wprowadzająca formuła „w tym dniu” każe przypuszczać, że wiersze te są późne. ${ }^{130}$

„W tym dniu zasłabną ${ }^{131}$ piękne, młode kobiety

${ }^{128}$ Poza za tym pojawia się jeszcze sformułowanie „Duma Jakuba” w 6,8 i 8,7; zob. H. W. W o $1 \mathrm{ff}$, Dodekapropheton 2, s. 400.

${ }^{129}$ Szczegóły w J. J e r e m i a s, Amos 8,4-7-ein Kommentar zu 2,6f, w: t e n ż e, Hosea und Amos, s. 231-243; t e n ż e, Der Prophet Amos, s. 114-115, 120-121. Kompozycja ta (choć inaczej wydzielona) jest wtórna także zdaniem H. W. W o 1 f fa, Dodekapropheton 2, s. 373-375.

${ }^{130}$ Formuła ta, przypuszczalnie związana z „dniem JHWH” (por. Am 5,18-20), ma zasadniczo eschatologiczny wydźwięk i pojawia się w młodszych tekstach; M. Sæbø, aי, w: TWAT III, s. 584. Wg H. W. W o $1 \mathrm{f} \mathrm{f} \mathrm{a,} \mathrm{Dodekapropheton} \mathrm{2,} \mathrm{s.} \mathrm{374;}$ Am 8,13-14, choć zdradzają wpływ Oz, to z powodu wzmianki o Dan nie powinny być datowane zbyt późno, tj. przed najazdem Tiglatpilesera w 733 r. p. n. e. W mojej ocenie wymienienie Dan nie może być rozstrzygające, gdyż może wraz z Beerszebą może być tradycyjnym określeniem całej ziemi obiecanej (zob. poniżej).

${ }^{131}$ Forma czasownika jest zgodna z następującym bezpośrednio rzeczownikiem, choć rzeczowo obejmuje też „młodzieńców”; do tego H. W. Wo $1 \mathrm{ff}$, Dodekapropheton 2, s. 372 . 
i młodzieńcy z powody pragnienia ${ }^{132}-$ ślubujący na winę (Aszimę) $)^{133}$ Samarii i mówią: «Jak żyje Bóg twój, Dan!» $\mathrm{i}$ «Jako żyje droga do (Moc) ${ }^{134}$ Beerszeby!», tak że upadną i już więcej nie powstaną".

Fragment ten, podejmując motywy z bezpośredniego kontekstu, jest groźbą skierowaną przeciwko młodym kobietom (por. 5,2) i młodzieńcom, którzy w powodu braku wody zasłabną i umrą - ich upadek będzie ostateczny (ramowa pozycja w. 13-14b). Nawet pełni wigoru młodzi nie przetrwają. Być może reprezentują oni cały lud, społeczność. ${ }^{135}$ Sprawca ich zguby, którym musi być sam Bóg, też nie jest wprost wzmiankowany. Ślubowania przynależały do kultu.

${ }^{132}$ Nie ma żadnego powodu tekstowo-krytycznego, bo nie może nim być dążenie do stworzenia idealnego paralelizmu synonimicznego, do zmiany rzeczownika, który wiąże te wiersze z poprzedzającymi w.11-12, na przymiotnik ,silni” - wbrew BHS (prp); zob. H. W. Wolff, Dodekapropheton 2.

${ }^{133}$ W TM możemy mieć do czynienia zarówno z enigmatycznym wskazaniem na bałwochwalcze praktyki („wina” będąca epitetem bóstwa), jak i z korektą dogmatyczną. H. W. Wolff wskazuje, że bogini Aszima - אִשְימאוא $(2 \mathrm{Krl} 17,30)$ pojawia się jedynie w powiązaniu z syryjskim Chamat (Hamat). Dużo dalej idąca byłaby korekta Aszera/aszera proponowana w BHS. Zob. HAHAT.

${ }^{134}$ W TM „droga” w sensie ,pielgrzymki” do Beerszeby (tak tłumaczy W. R u d o 1 p h, Joel, Amos, Obadja, Jona, s. 268). Jest to sytuacja analogiczna do „winy

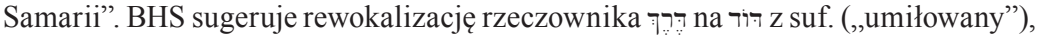
który mógłby być imieniem własnym (wtedy nie może być mowy o suf., co wymagałoby ingerencji w tekst spółgłoskowy) bóstwa chroniącego dane miejsce święte (znajduje poświadczenie w inskrypcji ze steli Meszy; H. W. W o l f f, Dodekapropheton 2, s. 372). Ostatnio częściej przyjmuje się wywodzenie znaczenia rzeczownika z ugaryckiego $d r k t$ w znaczeniu ,panowanie” (zob. HAHAT) lub „siła”, „moc” (zob. HAL, H. W. Wolff). W tym ostatnim znaczeniu i w odniesieniu do bóstwa H. W. Wolff, Dodekapropheton 2 i J. J e r e m i a s, Der Prophet Amos, s. 114.

${ }^{135}$ Tamże, s. 120, sądzi, że ze względu na w. 14a chodzi o mieszaną społeczność powstałą po wygnaniu dużej części mieszkańców północnego Izraela (Ne 3,33nn.), ale trzeba pamiętać, że jest to tekst polemiczny z późnego okresu, być może nawet helleńskiego; do tego S. G r ät z, Das Edikt des Artaxerxes. Eine Untersuchung zum religionspolitischen und historischen Umfeld von Esra 7,12-26, BZAW 337, Berlin-New York 2004, co kazałoby datować również ten wiersz bardzo późno. 
Były nadal składane, ale nie na Boga JHWH, lecz inne bóstwa. Ślubować (שבע ni.), przywołując na gwaranta Boga czy bóstwo, oznacza wyznawać danego Boga/boga, podporządkowywać mu się i być mu posłusznym. ${ }^{136}$ Bez względu na to, jak rozumieć poszczególne określenia związane z Samarią, Dan i Beerszebą, czyli stolicą królestwa izraelskiego oraz miastami położonymi na północnej i południowej granicy Izraela i Judy, co zdaje się wskazywać na cały lud izraelski, Izraela i Judę (z jakiegokolwiek okresu), mowa jest z pewnością o praktykach bałwochwalczych. Jeśli w tekście nie chodzi o Aszimę (2Krl 17,30), to być może o kult byka, cielca z Betel (i Dan; por. $1 \mathrm{Krl}$ 12,29), co mógłby sugerować Oz 8,5-6. ${ }^{137}$ „Boga z Dan”, wspomina aramejsko-grecka inskrypcja $\mathrm{z}$ okresu helleńskiego, ${ }^{138}$ a Beerszeba może być związana z dodatkiem w 5,5 (zob. powyżej). Tak czy inaczej, fragment ten jest krytyką praktyk bałwochwalczych, być może obecnych w Palestynie w okresie późno-po-wygnaniowym.

Również wiersze 8,9-10 są częścią wtórnej kompozycji 8,3-14 i zdają się związane z powyżej omówionym fragmentem 8,13-14.

„I stanie się w tym dniu - wyrocznia Pana JHWH. ${ }^{139}$

że sprawię, iż zajdzie słońce w południe,

i zaciemnię ziemię $\mathrm{w}$ jasnym dniu;

i przemienię wasze święta w żałobę,

a wszystkie wasze pieśni w pieśń żałobną,

i wciągnę na wszystkie biodra wór

i na każdą głowę łysinę,

i uczynię ją ${ }^{140}$ jak żałobę po jedynaku,

a jej koniec jak gorzki dzień".

${ }^{136}$ C. A. K e 11 e r, שבע, w: THAT II, s. 860-862, zwł. s. 861.

137 Zob. H. W. W o 1 ff, Dodekapropheton 2, s. 381.

138 J. J e r e m i a s, Der Prophet Amos, s. 121.

${ }^{139} \mathrm{~W} \mathrm{G}^{*}$ odnajdujemy lekcję krótszą (zob. BHS), ale niekoniecznie starszą, gdyż może wynikać ze zlania się obu określeniem Boga, które występują w TM.

${ }^{140}$ Suf. odnosi się do pieśni żałobnej lub jak chce H. W. W o $1 \mathrm{ff}$, Dodekapropheton 2, s. 379, ma znaczenie odpowiadające naszemu rodzajowi nijakiemu, wskazując na żałobę z jej wszystkimi elementami. 
Po typowej dla późniejszych rozszerzeń formule „w tym dniu” $(9,8 \mathrm{a} \alpha$; por. 8,13$)$ następuje zapowiedź nastania ciemności za dnia, przy czym nie musi chodzić o zaćmienie słońca, ${ }^{141}$ lecz o cytat z 5,18-20, tj. o dzień JHWH, który jako dzień sądu nad Izraelem okazuje się ciemnością w opozycji do zbawiennej jasności. Wtedy Bóg sprawi, że uroczystości kultowe, o których mowa w 5,21-23, zostaną zamienione $\mathrm{w}$ żałobę $-8,10$ przywołuje różne ryty żałobne, w tym pieśń żałobną qina ${ }^{\mathrm{h}}$ (por. 5,1.16-17 i powyżej). Zwraca uwagę nagromadzenie wyrażeń dla żałoby i jej wzmocnienie przez wyrażenie ,żałoba po jedynaku". ${ }^{142}$ Nawet koniec żałoby nie przyniesie ulgi, lecz będzie gorzki. Redaktor ukazuje zapowiedziany w czwartej wizji „koniec” jako całkowitą zagładę i zerwanie relacji z Bogiem zarówno w kulcie, jak i za pośrednictwem prorockiego słowa $(8,12){ }^{143}$

$$
* * *
$$

Księga Amosa jest literacko złożoną księgą, zawierającą wypowiedzi z różnych okresów historii Izraela, Judy i społeczności powygnaniowej. Trudno byłoby mieć co do tego wątpliwości, nawet gdy analizę ogranicza się do tekstów krytycznych wobec kultu.

1. Krytyka kultu w najstarszych fragmentach mogących bazować na ustnym przekazie Amosa podważa sens kultu jako takiego, gdyż relacja z Bogiem jest możliwa również bez kultu i ofiar $\left(5,25^{*}\right)$. Jednak nie tyle neguje się sens kultu w ogóle, ile pokazuje, że w wyniku nieprawości społecznych kult przestaje być sposobem łączności ludu z Bogiem. Bóg sam unieważnia taki sposób docierania do Niego z modlitwą i dziękczynieniem. Kult bez zachowywania prawa,

${ }^{141}$ Najczęściej rozumie się ten czasownik jako mówiący o zaćmieniu słońca, np. tamże, s. 378; E. Z a w i s z e w s k i, Księga Amosa, s. 246.

${ }_{142}$ Zob. przede wszystkim J. J e r e m i a s, Der Prophet Amos, s. 119. Do uroczystości żałobnych zob. E. K u t s c h, ,,Trauerbräuche” und „Selbstminderungsriten” im Alten Testament, w: t e n ż e, Kleinen Schriften zum Alten Testament, BZAW 186, Berlin-New York 1986, s.78-95.

${ }^{143}$ W kompozycji 8,3-14 powracają tematy z 5,1-17, a mianowicie żałoba i krytyka kultu. 
uczciwego i bezstronnego sądzenia, które umożliwiłoby biedakom dochodzenie swoich praw, bez sprawiedliwości, czyli wzajemnej lojalności społecznej, troski o poszkodowanych przez zamożnych i stojących wyżej w hierarchii społecznej czy los, traci znaczenie. Bezwzględnie piętnuje się przy tym wyzysk ekonomiczny. Warunkiem zbawiennej łączności z Bogiem jest sprawiedliwość społeczna. Szukanie Boga nie polega na pielgrzymowaniu do świątyń, oddawaniu tam czci i proszeniu o pomoc, lecz na czynieniu bliźniemu szeroko pojętego dobra. Z powodu nieprawości Bóg srogo ukarze Izraela. Nieprawości kultowe, takie jak niewierność Bogu JHWH czy praktyki religijne, które piętnuje Ozeasz (por. np. Oz 4,4-19), pozostawały poza zainteresowaniem Amosa i jego bezpośrednich uczniów.

2. Nawet w tekstach, które zdają się zdradzać wpływy Ozeaszowe $(2,8 ; 7,9)$ i zostały skierowane przeciwko świątyniom i wszelkim instalacjom kultowym, przyczyną Bożej kary pozostaje nieprawość społeczna i wyzyskiwanie ubogich, dzięki którym bogacze mogą radośnie, w zadufaniu, ucztować w ramach uroczystości kultowych. Bóg zniszczy miejsca kultu i królestwo.

3. Dopiero wygnaniowo-powygnaniowe redakcje (w tym ,judejska”) przesuwają akcent z nieprawości społecznych na niewierność religijną w duchu teologii deuteronomistycznej $(3,13-14$; dodatek w 5,5; 8,13-14). Uzupełnienia ukazują nieszczęścia, narodową katastrofę, które spotkały oba królestwa. Bóg sam położył kres również dotychczasowemu kultowi, a jedyną możliwą formą kultu stają się nabożeństwa pokutne i żałoba. Wspólnotę powygnaniową trzeba znów ostrzegać przed winami, które doprowadziły do katastrof: niesprawiedliwością społeczną, zgubną rolą państwa-królestwa i bałwochwalstwem.

Jak słusznie zauważa E. Zawiszewski, w Księdze Amosa nie znajdziemy ani jednej pozytywnej wypowiedzi o kulcie, ${ }^{144}$ co być może nie dotyczy nabożeństw pokutnych (żałoby). Autorzy księgi nie przekreślają całkowicie kultu jako takiego, nawet jeśli możliwa jest relacja z Bogiem bez ofiarnictwa i uroczystości kultowych.

${ }^{144}$ E. Z a w is z e w s k i, Księga Amosa, s. 172. 
O przyszłości ludu i społeczności izraelskiej rozstrzyga jednak nie tyle kult, ile sprawiedliwość społeczna, troska o ubogich, prawe sądzenie, dbanie o dobro bliźniego oraz wierne oddanie JHWH. Dopóki do Księgi Amosa nie zostały dodane zarzuty o bałwochwalstwo, religijna prawomocność kultu w północnym Izraelu nie była w niej w ogóle kwestionowana - był to kult Boga JHWH, a jego znaczenie podważały nieprawe czyny jego uczestników, wymierzone w biednych i potrzebujących. Nie znajdziemy żadnego zachęcenia do pielgrzymek i uczestniczenia w kulcie w Jerozolimie. ${ }^{145}$ Wszystko wskazuje na to, że Amos i jego uczniowie, pierwsi tradenci nie mieli pojęcia o „centralizacji kultu” z tzw. Deuteronomistycznego dzieła historycznego, ${ }^{146}$ poprzedzali sformułowanie takiego programu.

Jakub SLAWIK

${ }^{145}$ Wbrew tezom E. Zawiszewskiego i G. Witaszka (zob. powyżej).

${ }^{146}$ Zob. W. H. S c h m i d t, Wprowadzenie do Starego Testamentu, s. 118-125. 